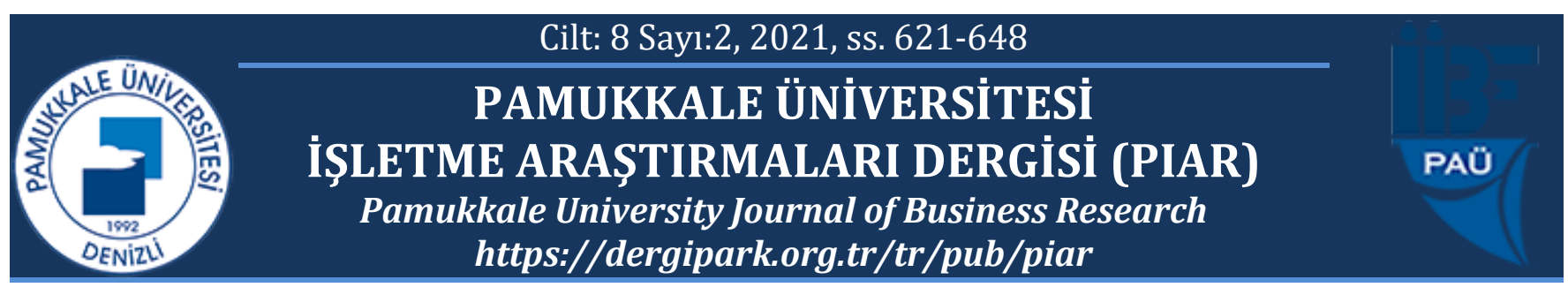

\title{
Psikolojik Sözleşme ile Örgütsel Özdeşleşme Arasındaki İlişkiye Yönelik Bir Araştırma*
}

\section{A Research On The Relationship Between The Psychological Contract and Organizational Identification}

\section{Baki Can ÇÖLLÜ ${ }^{* *}$}

\section{Esin BARUTÇU ${ }^{2}$}

\author{
${ }^{1}$ bakicancollu20@gmail.com, https://orcid.org/0000-0002-3461-2270 \\ 2 Pamukkale Üniversitesi, İktisadi ve İdari Bilimler Fakültesi İşletme Bölümü, esahin@pau.edu.tr, \\ https://orcid.org/0000-0001-6950-4117 \\ ** Yazışılan Yazar/Corresponding author
}

Makale Geliş/Received: 20.11.2021

Makale Kabul/Accepted: 21.12.2021

\begin{abstract}
Öz
Işletmelerin, performans ve verimliliklerini en iyi düzeye getirebilmeleri için örgüt ile işgörenler arasındaki ilişkiye önem vermeleri gerekmektedir. Bu doğrultuda, iki taraf arasında yapılan iş sözleşmelerinin değişen ve gelişen rekabet ortamında yetersiz kalmaya başladığı gözlemlenmiştir. Bu sebeple, taraflar arasında karşılıklı beklentilerin ve yükümlülüklerin olduğu yazılı olmayan psikolojik sözleşme kavramı ön plana çıkmıştır. Psikolojik sözleşmeler, maddi beklentilerin (iş, ücret), yanında manevi beklentilerin (kariyer, zaman, eğitim, sadakat, vb.) olduğu sözleşmelerdir. Psikolojik sözleşmeye uygun davranıldığı durumda işgörenler, örgüte karşı daha fazla güven, bağhllk să̆layacak hatta örgütle kendilerini özdeşleştireceklerdir. Örgütle özdeşleşen işgörenler, örgütle kendini bir görerek, örgütün verimlilĭginin ve kazancının artması için daha fazla gayret gösterecektir. Bu kapsamda yapılan bu çalışma psikolojik sözleşme ile örgütsel özdeşleşme arasındaki ilişkiyi analiz etmek amacı ile yapılmıştır. Bu çalışma, Acıpayam Belediyesi personeli üzerinde gerçekleştirilmiştir. Araştırmaya 147 belediye personeli katılmıştır. Araştırma kapsamında yapılan analiz sonucunda, psikolojik sözleşme ile örgütsel özdeşleşme arasında pozitif yönlü orta kuvvette anlaml bir ilişkinin olduğu görülmüştür.
\end{abstract}

Anahtar kelimeler: Psikolojik Sözleşme, Örgütsel Özdeşleşme, Kamu Kuruluşu, Sözleşme

JEL kodlart: M10, L20

\begin{abstract}
Businesses need to pay attention to the relationship between the organization and employes who work in order to maximize their performance and efficiency. Accordingly, it has been observed that labor contracts between both parties are becoming inadequate in a changing and developing competitive environment. For this reason, the concept of an unwritten psychological contract in which there are mutual expectations and obligations between the parties has come to the fore. Psychological contracts include material expectations (work, wages), as well as spiritual expectations (career, time, education, loyalty, etc.) are contracts. If they are treated in accordance with the psychological contract, those who work will provide more trust, commitment to the organization, or even identify themselves with the organization. Employees who identify with the organization, seeing themselves with the organization, will make more efforts to increase the efficiency and profit of the organization. In this context, this study was conducted to analyze the relationship between psychological contract and organizational identification. This study was carried out on staff of Acipayam Municipality. 147 municipal personnel participated in the survey. As a result of the analysis conducted within the scope of the research, it was found that there is a significant relationship between psychological contract and organizational identification in a positive direction of medium strength.
\end{abstract}

Keywords: Psychological Contract, Organizational Identification, Public Organization, Contract

JEL codes: M10, L20

\footnotetext{
* Bu çalışma, Baki Can ÇÖLLÜ'nün "Psikolojik Sözleşme ile Örgütsel Özdeşleşme Arasındaki İlişkiye Yönelik Bir Araştırma" başlıklı Yüksek Lisans Tezi'nden türetilmiştir.
} 


\section{GİRIŞ}

Psikolojik sözleşme kavramı, işveren ve işgören arasında sadece maddi beklentilerin (iş/ücret) olmadığını bunun yanında karşılıklı olarak manevi beklentilerin (kariyer, terfi, eğitim, performans, sadakat vs.) olduğunu ifade etmektedir. Psikolojik sözleşmeler yazılı olmayan, işveren ile işgören arasında sözlü olarak yapılan gizli bir sözleşmedir. Psikolojik sözleşme doğrultusunda işveren ve işgörenin karşılıklı beklentileri yerine getirmeleri işletmelerin daha verimli hizmet sağlaması, değişen dünya koşullarına kolay adapte olması gibi birçok etmenin daha sağlıklı ve kolay yürütülmesini sağlayacaktır. Bu sebeplerden dolayı işletmelerin psikolojik sözleşme kavramının önemini kavramaları ve bu kavramın gerekliliklerini yerine getirmeleri, işletmelerin daha verimli ve değişen koşullara adapte olmaları açısından önemli bir yer edinmektedir. Psikolojik sözleşme koşullarını yerine getiren işletmeler, işgörenler tarafından daha fazla tercih edilen bir konuma gelerek daha kalifiye bir çalışan kadrosuna sahip olacaklardır. Bunun yanında mevcut işgörenlerde işine daha fazla sahip çıkma ve mevcut işletmelerde de konumlarını koruma içgüdüsü meydana gelecektir. Bu koşullar işletme performansının sürekli olması ve işgörenlerin motivasyonunun artmasina neden olacaktır.

Psikolojik sözleşme gerekliliklerini işveren yerine getirdiği takdirde işgörenlerin çalışmakta oldukları işletmeye karşı bağlılıklarının artmasına neden olacaktır. Hatta işgörenler işletme ile olan bağları arttıkça kendilerini işletme ile bir bütün halinde görmeye başlayacaklardır. $\mathrm{Bu}$ noktada örgütsel özdeşleşme kavramı ön plana çıkmaktadır. Örgütsel özdeşleşme kavramı kısaca, işgörenlerin kendilerini işletme ile bir bütün olarak görmeleri olarak tanımlanabilir. Örgütsel özdeşleşme düzeyleri yüksek olan işgörenler kendilerini işletmenin yerine koydukları için işletmenin daha verimli olması daha fazla gelir elde etmesi için daha fazla performans gösterecektir. Örgütsel özdeşleşme ile psikolojik sözleşme kavramları sadece özel sektör kuruluşları açısından değil kamu kuruluşları açısından da önemli yer tutmaktadır. Kamu kuruluşu olan belediyelerin istikrar ve güven ortamını sağlamak için gerçekleştirdiği hizmetleri en iyi ve verimli şekilde gerçekleştirmesi gerektirmektedir. Belediyeler gerçekleştirdiği hizmeti personeli aracılığıyla vatandaşa sunmaktadır. Belediyenin sunduğu bu hizmeti en iyi şekilde gerçekleştirmesi için personeli ile olan ilişkisine önem vermesi gerekmektedir. Bu sebepten psikolojik sözleşme ile örgütsel özdeşleşme kavramları belediye ile personel arasında önemli bir kavram olarak düşünülerek çalışma belediye personeli üzerinde yapılmıştır. Bu doğrultuda yapılan çalışmada psikolojik sözleşme ve örgütsel özdeşleşme kavramları hakkında bilgi verilmiştir. Araştırma belediye personeli üzerinde anket tekniği uygulanarak gerçekleştirilmiştir. Elde edilen veriler SPSS programı ile analiz edilerek, elde edilen bulgular değerlendirilmiştir.

\section{KAVRAMSAL ÇERÇEVE}

\subsection{Psikolojik Sözleşme}

Sözleşme, her yerde ve her örgütte gerekli olan önemli bir unsurdur. Örgütlerle bireyleri bir araya getirerek onların davranışlarını ve tutumlarını düzenleyerek örgütsel amaçlara ulaşılmasında etkin rol oynar (Robinson vd., 1994: 137). Sözleşme tanımı, en genel anlamıyla en az iki ya da daha fazla tarafın birbirlerine karşı olan yükümlülüklerine olan inanışları olarak tanımlanmıştır (Rousseau, 1995: 6). Küreselleşme ile birlikte birçok kavramda değişim meydana gelmiştir. Klasik kavramların yerine gelen çağdaş kavramlar klasik 
kavramların önemini azaltmakta ya da bu kavramların yerine geçmektedir. Bu zaman sürecinde işletme alanında kavramlar değişmiş, gelişmiş ve yeni kavramlar ortaya çıkarak zenginleşmiştir. Bu değişim furyasından etkilenen kavramlardan biri de iş sözleşmeleridir. $\mathrm{Bu}$ değişimle birlikte sözleşmelere ek olarak literatüre giriş yapan bir başka kavram psikolojik sözleşmelerdir (Kıyık, 2011: 11).

Psikolojik sözleşmeler, iş sözleşmelerindeki boşlukları doldurmasından dolayı iş yaşamındaki işveren ile işgören arasında karşılıklı yükümlülük algısı oluşturmaktadır. $\mathrm{Bu}$ oluşturduğu karşılıklılık algısı işveren ile işgörenlere birtakım sorumluluklar yüklemektedir (Y1ldız vd., 2016: 148; İyigün ve Çetin, 2012: 16; Sels vd., 2004: 462).

Psikolojik sözleşme kavram olarak ilk kez 1960'lı yıllarda işveren ve işgören arasındaki beklentileri tanımlamak amacı ile kullanılmaya başlanmıştır (Hui vd., 2004: 311). Psikolojik sözleşme kavramı, daha sonra zaman içinde gelişim göstererek ve daha öznel bir yapıya bürünerek daha çok işgörenlerin algıları ve beklentileri üzerinden tartışma konusu olmuştur (Topçu, 2015: 11). Argyris (1960), psikolojik sözleşme kavramını işveren ve işgören arasında oluşan, iki ya da daha fazla kişinin birbirlerine karşı koydukları kurallara uyan, yazılı ve resmi olmayan sözleşme olarak tanımlamıştır (Anderson ve Schalk, 1988: 638).

Psikolojik sözleşmenin, tüm bu özelliklerine ilave olarak Levinson'ın (1962) ortaya koyduğu özellikler şu şekilde ifade edilebilir (Topaloğlu ve Arastaman, 2016: 27);

- Psikolojik sözleşmeler, yazılı değildir, algılara dayanır.

- Psikolojik sözleşmeler, karşılıklı olarak beklentilere dayanır ve bireyleri bağlar.

- Psikolojik sözleşmelerin biçimsel özelliği yoktur ve ilişkisel özellik taşırlar.

- Psikolojik sözleşmeler, dinamik değişken yapıdadır.

- Psikolojik sözleşmede taraflar uzlaşma konusunda hemfikir olamayabilir.

- Psikolojik sözleşmeler, tarafların duygularına şekil verir, yani kapalı bir yapıya sahiptir.

Rousseau ve Schalk (2000), psikolojik sözleşmenin oluşması için iki şarttan bahsetmiştir. İlk olarak, psikolojik sözleşme belirli bir şahsi özgürlük içermelidir. İkinci olarak ise, psikolojik sözleşmenin oluşması için sosyal kararlılık önemli bir ihtiyaçtır. Psikolojik sözleşmede işveren ile işgörenin karşılıklı olarak güven duyması gerekmektedir (Karcıŏ̆lu ve Türker, 2010: 123). Psikolojik sözleşmenin oluşmasında öncelikli koşullar işgörenin özgür iradesi ve sosyal kararlığından meydana gelmektedir (Morrison, 1994: 355).

Psikolojik sözleşmede, birey ile örgütün birbirine karşı olan yükümlülükleri örgütün başarısı ve sürekliliği için iyi analiz edilip uygulanması gerekmektedir (Schein, 1978: 14). Psikolojik sözleşmede tarafların birbirlerine karşı olan bazı yükümlülükleri aşağıdaki Tablo 1'de gösterilmektedir.

Tablo 1. Psikolojik Sözleşmede Tarafların Yükümlülükleri

\begin{tabular}{|l|l|}
\hline ÇALIŞANLARIN YÜKÜMLÜLÜKLERİ & $\begin{array}{l}\text { İŞVEREN } \\
\text { YÜKÜMLÜLÜKLERI }\end{array}$ \\
\hline
\end{tabular}




\begin{tabular}{|l|l|}
\hline Çok çalışmak & $\begin{array}{l}\text { Performansa uygun olarak eşit } \\
\text { ücretlendirme yapmak }\end{array}$ \\
\hline Örgüt itibarını korumak & $\begin{array}{l}\text { Çalışanlarına kendini yetiştirme yönünde } \\
\text { eğitim olanakları oluşturmak }\end{array}$ \\
\hline $\begin{array}{l}\text { İşyerine vaktinde ulaşmak ve mesai } \\
\text { saatlerine azami derecede bağlı kalmak }\end{array}$ & Kariyer olanakları sağlamak \\
\hline Örgüte karşı bağlılık göstermek & Yenilikçiliğe teşvik etmek \\
\hline İhtiyaç halinde fazla mesai yapmak & Performans ile ilgili geribildirim yapmak \\
\hline \begin{tabular}{l} 
Esnek olabilme çalışmalarını \\
\hline Yeni beceriler kazanmak
\end{tabular} & $\begin{array}{l}\text { Başkalarının } \\
\text { denetleyebilmek }\end{array}$ \\
\hline $\begin{array}{l}\text { İş arkadaşlarına ve müşterilere saygılı } \\
\text { davranmak }\end{array}$ & $\begin{array}{l}\text { Ģalışanlara ve müşterilere ilgi çekici hale getirmek saygılı } \\
\text { davranmak }\end{array}$ \\
\hline
\end{tabular}

Kaynak: CIPD, 2010: 3

Psikolojik sözleşmede taraflar karşılıklı olarak kendilerine düşen yükümlülükleri yerine getirdiğinde hem psikolojik sözleşmenin yapısı hem de taraflar açısından pozitif sonuçlar ortaya çıkacaktır (Demiral, 2008: 44).

Psikolojik sözleşme, işveren ve işgören arasındaki karşılıklı olan yükümlülük ve beklentilere yönelik bireyin algı ve inançları olarak tanımlanır (Rousseau, 1990: 389). Psikolojik sözleşme içerisindeki beklentilerin, sıradan beklentilerden daha güçlü ve farklı olması, sözleşmedeki beklentilerin algılanan sözlerden meydana gelmesinden dolayıdır (Rousseau ve Tijoriwala, 1998: 680). Kotter'in psikolojik sözleşmede çalışan ve örgütün beklentilerini ayrı ayrı analiz ederek ortaya çıkardığı maddeler aşağıdaki Tablo 2' de gösterilmiştir (Kotter, 1973: 93).

Tablo 2. Psikolojik Sözleşmede Tarafların Beklentileri

\begin{tabular}{|l|l|}
\hline ÇALIŞANIN BEKLENTİLERI & İŞVERENINN BEKLENTÍLERI \\
\hline Meslekte anlam amaç duygusu & $\begin{array}{l}\text { Belli derecede teknik bilgi ve beceri gerektiren } \\
\text { sosyal olmayan işle ilgili işleri yapabilme }\end{array}$ \\
\hline İşte gelişim fırsatları & $\begin{array}{l}\text { Görevdeyken bir pozisyonun çeşitli yönlerini } \\
\text { öğrenme }\end{array}$ \\
\hline Kariyer fırsatları & Yeni problemleri çözme yeteneği \\
\hline İşte güç ve sorumluluk & İnsan gruplarıyla verimli çalışabilme \\
\hline İşte durum ve prestij & İyi sunum yapabilme \\
\hline Maaş & $\begin{array}{l}\text { Başkalarından yardım almadan sorumlu } \\
\text { kararlar alabilme }\end{array}$ \\
\hline
\end{tabular}




\begin{tabular}{|c|c|}
\hline Çalışma grubunun uygunluğu & $\begin{array}{l}\text { Şirketin yararı için zaman ve enerji kullanma } \\
\text { yeteneği }\end{array}$ \\
\hline Farklı (ilginç) iş miktarı & $\begin{array}{l}\text { Kendisi veya başkaları için iş çabalarını } \\
\text { planlama ve organize etme }\end{array}$ \\
\hline İşteki güvenlik miktarı & İşin diğer üyeleriyle olan sosyal ilişkiler \\
\hline İyi bir iş için tanınma & Şirketin kamuya açık imajını korumak \\
\hline Geri bildirim ve değerlendirme sıklığ1 & $\begin{array}{l}\text { Şirket değerlerini ve kendi hedefleri olarak } \\
\text { görebilme }\end{array}$ \\
\hline
\end{tabular}

Kaynak: Kotter, 1973: 93

Psikolojik sözleşmenin çeşitli türleri olmasına rağmen ilişkisel ve işlemsel psikolojik sözleşmeler bir cetvelin iki ucunu temsil eden türlerdir (McDonald ve Makin, 2000: 85). Psikolojik sözleşmelere farklılaşan örgüt ortamları dikkate alınarak Rousseau ve WadeBenzoni tarafından iki tane psikolojik sözleşme türü daha eklenerek dört farklı türde incelenmiştir (Cihangiroğlu ve Şahin, 2010: 8). Psikolojik sözleşme türleri aşağıdaki Tablo 3'de gösterilmiştir.

Tablo 3. Psikolojik Sözleşme Türleri

\section{Performans}

\section{Belirli Belirsiz}

\begin{tabular}{|c|c|c|c|}
\hline & Kısa Dönem & İşlemsel & Geçişsel \\
\hline Zaman & Uzun Dönem & Dengeli & İlişkisel \\
\hline
\end{tabular}

Kaynak: Rousseau ve Wade-Benzoni, 1994: 468

Işslemsel sözleşmeler; kısa vadeli, kapsamı dar, maddi ödüllere dayanan halka açık sözleşmelerdir (Arnold, 1996: 153).

İlişkisel sözleşmeler; ucu açık, geniş ve uzun süreli yükümlülük altına sokan sözleşmelerdir. İlişkisel sözleşmeler, yalnızca maddi unsurlar için değil, güven ve sadakat gibi sosyoduygusal faktörlerin alışverişine de dayanır. (Morrison ve Robinson, 1997: 229).

Geçişsel sözleşmeler; gelecek ile ilgili vaatlerin olmadı̆̆1 ve performans isteklerini ve şartlı teşvikleri çok az ya da hiç göstermeyen sözleşmelerdir (Rousseau ve Wade-Benzoni, 1994: 468).

Dengeli sözleşmeler; işgören ve işveren için iyi bir şekilde belirtilen yükümlülükleri ve taraflar arasında uzun süreli katılım ihtimalini içerdiğinden dolayı işlemsel ve ilişkisel sözleşmelerin karışımından meydana gelmektedir. Fakat ilişkisel sözleşmelerden daha dinamik bir yapısı vardır (Petersitzke, 2009: 30).

Psikolojik sözleşmede işgören ile işveren birbirlerine olan taahhütlerini gerçekleştirmediğinde sözleşme ihlalleri kaçınılmaz bir hal alır (Top, 2012: 209). Psikolojik sözleşme ihlali ile ilgili çalışmalara bakıldığında, gerçekleşen ihlaller değil, algılanan ihlaller 
odak noktası olmuştur. Örgütün sözleşmedeki maddelerinin her ihlali, işgören açısından bir ihlal olarak değerlendirilmemesinin yanı sıra sözleşmenin zayıflaması anlamına da gelmez (Turney ve Feldman, 1999: 368). Psikolojik sözleşme kapsamında işveren ile işgörenin mübadele ilişkisi kapsamında yükümlülüklerini yerini getirip getirmeme durumuna göre çeşitli algıları oluşabilmektedir (Coyle-Shapiro ve Kessler, 2000: 905).

Psikolojik sözleşmenin ihlal edilmesi sonucunda işgörenin iş aramayı arttırması, görev ve sorumluluklarına daha az önem göstermesi neticesinde örgüte karşı daha az bağlılık göstermesi ve çalışma isteğinde azalma görülecektir (Özler ve Ünver, 2012: 330). Bunların yanı sıra işgörenler açısından ihlal sonucunda öfke, iş bırakma, performans düşüklüğü gibi belirtiler meydana gelmekte ihlal devam ettikçe güvensizlik, sabotaj ve duygusal yoksunluk gibi sonuçlar ortaya çıkabilmektedir. Bu sonuçların yanında ilişkisel psikolojik sözleşmeler, işlemsel sözleşmelere dönmektedir (Rousseau, 2004: 124).

\section{2. Örgütsel Özdeşleşme}

Özdeşleşme kavramı Freud tarafından ilk defa bir başkasıyla duygusal bağ kurma olarak tanımlanmıştır (Gautam vd., 2004: 302). Özdeşleşme, kişilerin bir bütün halinde hareket etmelerine neden olan ve karşılıklılık hissi yaratan sosyal bir süreçtir (Gosset, 2002: 386). Özdeşleşme kavramı Türk Dil Kurumu Sözlüğünde ise "Bir nesne veya bireyin bir kümenin tüm özelliklerini özümsemesi ya da bütünleşmesi” olarak tanımlanmıştır (TDK, 2020).

Örgütsel özdeşleme kavramı 1943'de Edward Tolman tarafından yapılan çalışma ile ortaya koyulmuştur (Köse, 2009: 2). Edward Tolman, özdeşleşmeyi üç türde açıklamıştır (Tolman, 1943: 141-142):

- $\quad$ İlki, özdeşleşme kişinin kendinden büyük (araştırdığı veya hayran olduğu) kişiyi kopyaladığı süreçtir.

- $\quad$ İkincisi, kişinin kendisini parçası olarak gördüğü gruba bağlı olmasıdır.

- $\quad$ Son olarak, özdeşleşme bir nedenin kişi tarafından kabul edilmesidir.

Örgütsel özdeşleşme kavramı örgütsel alanda ise 1960'lardan itibaren çalışmalara konu olmaya başlamıştır (Boroş, 2008: 1). Örgütsel özdeşleşme, kişi ve örgütün etkinliğine etki eden, örgütsel davranışa yönelik eleştirel bir kavram olarak kabul edilmektedir. Bunun yanında örgütsel özdeşleşme kavramı, örgütsel bağlılık ve benimseme gibi kavramlarla karıştırılmaktadır (Ashforth ve Mael, 1989: 20).

Knippenberg, örgütsel özdeşleşmeyi bireyin grubun içinde rahat davranabilmesi için kurduğu duygusal bağ ve örgütün değerlerini benimsemesi olarak tanımlamıştır. Bireyin, bir grup veya örgütle özdeşlemesi taraflar arasında psikolojik bağlılık meydana getirmektedir (Van Knippenberg, 2000: 360). Bireylerin örgütlerle özdeşleşmesi, bireylerin diğer gruplar ile olan ilişkilerinde örgütün temsilcisi gibi hareket ederek, kendi çıkarlarını korudukları gibi örgütün çıarlarına da sahip çıkmalıdır. Bireyler, kendilerini örgütleri ile özdeşleştirdiklerinde örgütün hedeflerinin kendi hedefleri olarak görmekte ve böylece örgüte karşı daha fazla verimli ve etkin çalışma göstermekte ve bunun yanında örgüte karşı uyumluluk ve sorumluluk davranışlar sergilemektedirler (Eroğlu vd., 2015: 1018).

Örgütsel özdeşleşme ile ilgili yapılan farklı tanımlamaların ortak noktası, örgütün üyesi olan bireyin örgüt üyeliğini, duygusal olarak (üyelikten gurur duymak vb.) ya da bilişsel olarak 
(Kendini örgütün parçası görme, örgütün değerlerini içselleştirme vb.) değerlendirilmesi veya ikisiyle birlikte bağlantı kurmasıdır (Riketta, 2005: 360-361). Örgütsel özdeşlemenin önemi dört şekilde açılanmıştır (Carmeli vd., 2007: 3):

- $\quad$ Özdeşleşme, bir kimlik tanımı olmakta ve bireyler bu sayede diğer ilişkilerini bu kimlik üstünden tanımlayıp kurmaktadırlar.

- $\quad$ Özdeşleşme, birçok faktöre sahip olmakla birlikte özellikle emniyet, aidiyet ve ilişki yönetimini kapsayarak belirsizliği en az seviyeye düşürmektedir.

- $\quad$ Özdeşleme, örgüt ile çalışan arasındaki ilişkilerde ana unsur olmakta ve birçok çeşitli örgütsel faktörü etkilemektedir.

- $\quad$ Son olarak özdeşlemenin iş hayatında önemli olan liderlik ve adalet kavramları ile ilişkili olmasıdır.

Örgütler uzun vadeli hedeflerine ulaşmak için örgüt ile özdeşleşmiş çalışanlarla çalışma arzusunda olurlar. Örgütüyle özdeşleşen çalışma arzusu, verimlilik ve etkinlik problemini aşmada daha az maliyet ile hedefleri gerçekleştirmektir. Bu sebeplerden dolayı örgütlerin bireyin örgütle özdeşleşmesi adına ne yapılması gerektiği sorusunu cevaplandırması gerekmektedir. Bu soru yanıtlanırken, örgütlerin özdeşleşme sürecinin ekonomik eylemlerden daha farklı olduğunu göz önüne alarak yönetmesi gerekmektedir (Dutton vd., 1994: 260).

Örgütsel özdeşleşme, bireylerin örgütsel aşamaları daha iyi anlamasını ve geliştirmesini sağlayan bir faktördür. Örgüt ile özdeşleşme bireylerin, örgüte yönelik olumsuz davranış ve düşüncelerin ortadan kalkmasını sağlamaktadır. Bu durum, örgütüyle özdeşleşen bireylerin, örgütün belirlenen hedeflerine ulaşması için daha fazla emek vermeleri ve örgütün hedeflerine uygun davranışlar sergilemelerine yönelik beklentiye yol açmaktadır. Sonuç olarak, örgütüyle özdeşleşen bireylerin psikolojik durumları olumlu yönde etkilenecek ve bu olumlu hali örgütün bütün aşamalarına aktarabileceklerdir (Solnet, 2006: 581).

Örgütsel özdeşleşmenin olumlu sonuçlarının yanında olumsuz çıktıları da bazen oluşabilmektedir. İşgörenlerin kendi çalışma gruplarıyla özdeşleşme seviyesi yüksek olan örgütte, diğer çalışma gruplarına geçişi kolay olmayabilir. Zorunlu değişimlerde de istenmeyen çıktılar meydana gelebilmektedir. Bu sebeplerden dolayı grupla özdeşleme düzeyinin en üst seviyede olması bazı durumlarda olumlu sonuçlar doğurmayabilir (Van Knippenberg ve Schie, 2000: 145).

\subsection{Değişkenler Araşındaki İlişkiye Yönelik Tarama}

Psikolojik sözleşme ile örgütsel özdeşleşme arasındaki ilişkiye yönelik daha önce yapılmış olan çalışmalar ile benzer çalışmalara yer verilmiştir.

Topçu (2015) çalışanların kişilik özelliklerinin örgütsel özdeşleşme ve işten ayrılma niyeti üzerine etkisinde psikolojik sözleşme algısının rolünü incelemek amacıyla yaptığı çalışmayı, KOBİ kapsamında 421 kişi üzerinde uygulamıştır. Bu çalışmasında, psikolojik sözleşme algılarının örgütsel özdeşleme üzerindeki etkilerine baktığında, geleneksel psikolojik sözleşme ile ilişkisel psikolojik sözleşme algılarının, örgütsel özdeşleşme üzerindeki etkisinin anlamlı olduğu görülmüştür. 
Koyuncu (2019) psikolojik sözleşme ihlalinin örgütsel güven ve örgütsel özdeşleşme üzerine etkisini incelemek amacıyla yaptığı araştırmayı üniversitede çalışan 350 idari personel üzerinde uygulamıştır. Çalışma kapsamında psikolojik sözleşme ihlalinin, örgütsel özdeşleşme üzerinde olumsuz yönde etkisi olduğu görülmüştür.

Akyüz (2014) psikolojik sözleme ile örgütsel özdeşleşme arasındaki ilişkiyi incelemek adına yaptığı çalışmayı 203 kişi üzerinde uygulamıştır. Çalışma kapsamında yapılan analizin sonucunda psikolojik sözleşme ile örgütsel özdeşleşme arasında anlamlı bir ilişkinin olduğu görülmüştür.

Zagenczyk vd.'nin (2011) psikolojik sözleşme ve örgütsel özdeşleşmenin algılanan örgütsel desteğe aracılık etkisini incelemek adına yaptığ çalışma 177 kişi üzerinde gerçekleştirmiştir. Çalışma kapsamında işlemsel psikolojik sözleşme ihlalinin, örgütsel özdeşleşme üzerinde aracılık rolü olmadığı görülmüştür. İlişkisel psikolojik sözleşme ihlalinin, örgütsel özdeşleşme üzerinde aracılık etkisi görülmüştür. Bu sonuç, ilişkisel sözleşme ihlali durumunda kişilerin örgütsel özdeşleşmeye daha az yatkın olduğunu göstermiştir.

Wei ve Si (2013) psikolojik sözleşme ihlali, olumsuz karşılıklılık ve kötü niyetli denetim: örgütsel tanımlamanın aracılık etkisi adlı çalışmayı 268 kişi üzerinde gerçekleştirmişlerdir. Araştırma kapsamında psikolojik sözleşme ihlali ile örgütsel özdeşleşme arasında düşük düzeyde negatif ilişki görülmüştür.

Dikili (2012) psikolojik sözleşme ile iş tatmini ilişkisini anlamaya yönelik yaptığı çalışmayı 453 kişi üzerinde uygulamıştır. Çalışma kapsamında psikolojik sözleşmenin boyutları olan işlemsel psikolojik sözleşme ile ilişkisel psikolojik sözleşme boyutları açısından demografik faktörler arasından farklılaşıp farklılaşmadığına bakılmıştır. İşlemsel psikolojik sözleşme boyutu açısından demografik faktörler olan cinsiyet, eğitim ve sözleşme türüne anlamlı farklılık görülürken, diğer demografik faktörler olan medeni durum, yaş ve hizmet süresine göre anlamlı farklılık görülmemiştir. İlişkisel psikolojik sözleşme boyutu açısından, demografik faktör olan cinsiyet ve yaşa göre anlamlı farklılık görülürken, diğer demografik faktör olan medeni durum ve hizmet süresine göre anlamlı bir farklılık görülmemiştir.

Türker (2010) psikolojik sözleşme ile örgütsel bağlılık ilişkisini anlamaya yönelik yaptığ1 çalışmayı 978 kişi üzerinde gerçekleştirmiştir. Çalışma doğrultusunda psikolojik sözleşme açısından demografik faktör özelliklerine göre anlamlı farklılık olup olmadığına yönelik yapılan analiz sonucunda psikolojik sözleşmenin cinsiyet, yaş, medeni durumuna göre anlamlı farklılık taşıdığı görülürken, eğitim durumuna göre anlamlı bir farklılık görülmemiştir.

Kızıl'ın (2016) yöneticilerin stratejik liderlik davranışlarının kurumsal itibar algısı üzerine etkisinde örgütsel özdeşleşmenin ve kurumsal sosyal sorumluluğun rolünü incelemek amacıyla yaptığı çalışma 517 kişi üzerinde gerçekleştirilmiştir. Çalışma doğrultusunda örgütsel özdeşleşme açısından demografik faktör özelliklerine göre anlamlı bir farklılık olup olmadığına yönelik yaptığı analiz sonucunda, örgütsel özdeşleşmenin yaş, cinsiyet, eğitim ve çalışma sürelerine göre anlamlı bir farklılık görülmemiştir.

Serinkan ve Tülü (2021) tarafından örgütsel özdeşleşme ile örgütsel sinizm ilişkisini incelemek amacıyla yapılan çalışma 174 üniversite idari personeli üzerinde gerçekleştirilmiştir. Çalışma doğrultusunda yapılan analizde, örgütsel özdeşleşme açısından 
demografik faktörlerden yaş, cinsiyet, eğitim ve medeni durumuna göre anlamlı bir farklılık görülmemiştir.

\section{YÖNTEM VE BULGULAR}

\subsection{Araştırmanın Amacı, Evreni ve Örneklemi}

$\mathrm{Bu}$ araştırmada yapılan tanımlamalardan yola çıkarak, psikolojik sözleşme ve örgütsel özdeşleşme konularının, kavramsal tanımlamaları, özellikleri, kuramları ve sonuçları açıklanmıştır. Yapılan bu araştırmanın ana amacı psikolojik sözleşme ile örgütsel özdeşleşme arasındaki ilişkiyi, Acıpayam Belediyesi personeli üzerinde incelemektir. Ana amacın yanı sıra psikolojik sözleşme ile örgütsel özdeşleşme kavramlarının, demografik faktörler açısından farklılaşıp farklılaşmadığı analiz edilmiştir. Yapılan bu araştırma ile örgütün, personeli ile olan ilişkilerinin önemini ortaya çıkararak örgütlerin, personeli ile olan ilişkilerinde nasıl hareket edeceğine yönelik katkı vereceği düşünülmektedir.

Araştırmanın evrenini Denizli ili içerisindeki belediye çalışanları, örneklemini ise Acıpayam belediyesi çalışanları oluşturmaktadır. Veri toplama aracı olarak anket tekniği kullanılmıştır. Araştırma tanımlayıcı bir çalışmadır. Araştırmanın örneklemi kapsamda 232 belediye personeline anket gönderilmiş ve 147 anket değerlendirmeye alınmıştır.

\subsection{Kullanılan Ölçekler, Güvenirlilik ve Geçerlilik Analizi}

Yapılan araştırmada personelin psikolojik sözleşme algılarını ve örgütsel özdeşleşme düzeylerini belirlemek adına iki farklı ölçekten yararlanılmıştır. Araştırmada kullanılacak olan ölçekler seçilirken daha önce yapılan çalışmalarda daha çok tercih edilen ve güvenilir olan ölçekler seçilmeye özen gösterilmiştir.

Psikolojik sözleşme algısını ölçmek için Millward ve Hopkins (1998) tarafından geliştirilen, İyigün ve Çetin'in (2012) çalışmalarında kullandıkları "Psikolojik Sözleşme Ölçeği" kullanılmıştır. Ölçek 17 maddeden meydana gelmektedir. Örgütsel özdeşleşme düzeyini ölçmek için Mael ve Ashforth (1992) tarafından geliştirilen, Sökmen vd.'nin (2015) çalışmalarında kullanılan "Örgütsel Özdeşleşme Ölçeği” kullanılmıştır. Örgütsel özdeşleşme ölçeği 6 maddeden meydana gelmekte ve tek boyutludur. Araştırmada kullanılan her iki ölçek de'li likert tipinde (1-Kesinlikle Katılmıyorum, 2-Katılmıyorum, 3-Kararsızım, 4Katıliyorum, 5-Kesinlikle Katılıyorum) hazırlanmıştır.

Anketin ilk bölümde yer alan demografik faktörler ise "cinsiyet", "yaş", "'medeni durum", "eğitim", "kadro türü" ve "çalışma süresi" olarak 6 faktörden oluşmuştur. Anket çalışması yapılan kişilere yöneltilmek üzere toplamda 29 sorudan oluşan anket hazırlanmıştır.

Psikolojik sözleşme ölçeğinin güvenirlilik analizi sonucunda Cronbach Alfa değeri $\sqrt{\alpha=0,737}$ bulunmuştur. Bu sonuç ile ölçeğin güvenilir olduğu görülmüştür. Psikolojik sözleşme ölçeğinin alt boyutlarından olan işlemsel psikolojik sözleşme boyutunun Cronbach Alfa değeri 0,736 , ilişkisel psikolojik sözleşme boyutunun Cronbach Alfa değeri ise 0,811 bulunmuştur. Bu sonuçlardan yola çıkılarak işlemsel psikolojik sözleşme boyutunun oldukça güvenilir, ilişkisel psikolojik sözleşme boyutu yüksek seviyede güvenilir olduğu görülmüştür. Kullanılan örgütsel özdeşleşme ölçeğinin güvenirlilik analizi sonucunda ölçeğin Cronbach Alfa değeri 0,908 olarak bulunmuştur. Yapılan bu güvenirlilik analizi sonucunda ölçeğin yüksek sevide güvenilir olduğu görülmüştür. 
Psikolojik sözleşme ölçeğine uygulanan KMO ve Bartlett analizleri sonucunda KMO testinin değeri 0,778 ve Bartlett's küresellik testinin anlamlılık düzeyi (Sig.) 0,000 çıkmıştır. KMO değerinin, 0,5 değerinden büyük olması ve anlamlılık düzeyi (Sig.) değerinin 0,000 olmasından dolayı psikolojik sözleşme ölçeğinin geçerli olduğu tespit edilmiştir.

Psikolojik sözleşme ölçeğine yapılan $\mathrm{KMO}$ ve Bartlett testlerinin faktör analizine uygun olduğunun görülmesinden dolayı doğrulayıcı faktör analizi yapılmıştır. Faktör analizinde faktör yüklerinin 0,30 değerinin üzerinde olması istenmektedir. Bu doğrultuda yapılan doğrulayıcı faktör analizi sonuçları aşağıdaki Tablo 5 'te gösterilmiştir.

Tablo 5. Psikolojik Sözleşme Ölçeğinin Doğrulayıcı Faktör Analizi

\begin{tabular}{|c|c|c|c|}
\hline & \multirow[t]{2}{*}{ Ölçek İfadeleri } & \multicolumn{2}{|c|}{ Faktör ve Faktör Yükleri } \\
\hline & & İlişkisel & İşlemsel \\
\hline 13 & $\begin{array}{l}\text { Sıkı çalıştı̆̆ım takdirde bu kurumda } \\
\text { terfi edebilme imkânım vardır. }\end{array}$ & ,814 & \\
\hline 14 & $\begin{array}{l}\text { Çalıştığım kurumda kariyer planım } \\
\text { açık bir şekilde belirlenmiştir. }\end{array}$ & ,778 & \\
\hline 5 & $\begin{array}{l}\text { Şu an çalıştı̆̆ım kurumda ilerlemeyi } \\
\text { düşünüyorum. }\end{array}$ & ,745 & \\
\hline 16 & Bu kurumda sonuna kadar çalışırım. & 709 & \\
\hline 3 & $\begin{array}{l}\text { Hizmet sürem ve hedeflere ulaşmak } \\
\text { için gösterdiğim çaba karşıllı̆̆ında bu } \\
\text { kurumda yükselmeyi bekliyorum. }\end{array}$ & 648 & \\
\hline 8 & $\begin{array}{l}\text { Bu kurumda kendimi takımın bir } \\
\text { parçası gibi hissediyorum. }\end{array}$ & 607 & \\
\hline 10 & $\begin{array}{l}\text { Bu kurumun, çalışanların emeklerinin } \\
\text { karşılığını verdiğini düşünüyorum. }\end{array}$ & ,515 & \\
\hline 1 & İşimi sadece para için yapıyorum. & & 694 \\
\hline 2 & $\begin{array}{l}\text { Kesin olarak belirlenmiş çalışma } \\
\text { saatlerinde çalışmayı tercih ederim. }\end{array}$ & & 660 \\
\hline 11 & $\begin{array}{l}\text { Sadece işimin gereklerini yerine } \\
\text { getiriyorum. }\end{array}$ & & 600 \\
\hline 6 & $\begin{array}{l}\text { Her fazla mesai için ödeme yapılması } \\
\text { beklentim var. }\end{array}$ & & ,572 \\
\hline 7 & $\begin{array}{l}\text { İşe sadece işimi yapmak için } \\
\text { geliyorum. }\end{array}$ & & ,597 \\
\hline
\end{tabular}


12 Gelecekte alacağım hak ve menfaatler

, 493

(emeklilik, sağlık güvencesi vb.)

karşılı̆̆ında bu kuruma \%100 katkıda

bulunmaya hazırım.

4 İşte her şeye karışmamak önemlidir.

, 405

Psikolojik sözleşme ölçeğine uygulanan doğrulayıcı faktör analizi sonucunda ölçek ifadelerinin, ilişkisel ve işlemsel olmak üzere iki faktörde toplanmıştır. Faktör değeri incelendiğinde Fakat her iki boyutta yakın değere sahip olan 9'uncu madde olan "Çalıştığım kuruma olan sadakatim, sözleşmemdeki koşullarda belirlenmiştir" iki boyuttaki değeri 0,10 az olmasından dolayı değerlendirmeden çıkarılmıştır.

Faktör analizlerinde her bir maddenin faktör değerinin 0,30 değerinden büyük olması beklenir. Bu doğrultuda yapılan analizde, 15'inci madde olan "Sadece kısa dönemli iş hedeflerine ulaşmak istiyorum" maddesi ile 17'nci madde olan "Çalıştığım kurumda her şeye fazlasıyla karışırım “ maddesinin faktör değeri 0,30 değerinden küçük olduğu için değerlendirmeden çıkarılmıştır.

Yapılan analiz sonucunda açıklamanın varyans toplam düzeyi \%61 olarak bulunmuştur. Yapılan çalışmalarda toplam varyansın açıklama düzeyinin \%50nin üzerinde olması istendiğinden psikolojik sözleşme ölçeğinin faktör analizine uygun olduğu görülmektedir.

Örgütsel özdeşleşme ölçeğine yapılan KMO ve Bartlett testlerinin analizi sonucunda KMO değeri 0,839 ve Bartlett's küresellik testinin anlamlılık düzeyinin (Sig.) değeri 0,000 çıkmıştır. $\mathrm{Bu}$ sonuç doğrultusunda örgütsel özdeşleşme ölçeğinin faktör analizine uygun olduğu görülmüştür. Yapılan doğrulayıcı faktör analizi sonucunda örgütsel özdeşleşme ölçeğinin tek faktörden meydana geldiği görülmüştür. Örgütsel özdeşleşme ölçeğinin doğrulayıc1 faktör analizi aşağıdaki Tablo 6'da gösterilmiştir.

Tablo 6. Örgütsel Özdeşleşme Ölçeğinin Doğrulayıcı Faktör Analizi

\section{Ölçek İ́adeleri}

Faktör ve Faktör

Yükleri

Örgütsel

Özdeşleşme

\begin{tabular}{llc}
\hline 1 & $\begin{array}{l}\text { Başka biri çalıştı̆̆ım işletmeyi eleştirirse, bunu kişisel } \\
\text { hakaret olarak düşünürüm. }\end{array}$ &, 813 \\
\hline 2 & $\begin{array}{l}\text { Diğer insanları çalıştığım işletme hakkındaki } \\
\text { düşünceleri beni çok ilgilendirir. }\end{array}$ &, 798 \\
\hline 3 & $\begin{array}{l}\text { Çalıştığım işletme hakkında konuştuğumda; “onlar” } \\
\text { yerine “biz” kelimesini tercih ederim. }\end{array}$ &, 713 \\
\hline 4 & Çalıştığım işletmenin başarısı benim başarımdır. &, 658 \\
\hline 5 & $\begin{array}{l}\text { Başka biri çalıştığım işletmeyi övdüğünde, bunu kişisel } \\
\text { iltifat olarak düşünürüm. }\end{array}$ & \\
\hline
\end{tabular}


6 Medyada çalıştığım işletmeyle ilgili olumsuzluklar , 595 oluşursa, rahatsızlık hissederim.

Örgütsel özdeşleşme ölçeğinin doğrulayıcı faktör analizi sonucunda bütün faktör yüklerinin 0,30 değerinden yüksek olduğu görülmüştür. Yapılan analiz sonucunda açıklanan toplam varyansın \%68 olmasından dolayı ölçeğin geçerli olduğu tespit edilmiştir.

\subsection{Araştırmanın Modeli ve Hipotezleri}

Araştırmanın hipotezleri benzer çalışmalar incelenerek geliştirilmiştir (Dikili, 2012; Zengin, 2017; Envergil, 2018; Karabulut, 2019). Bu kapsamda oluşan araştırmanın hipotezleri aşağıdaki Şekil 1'de gösterilmiştir.

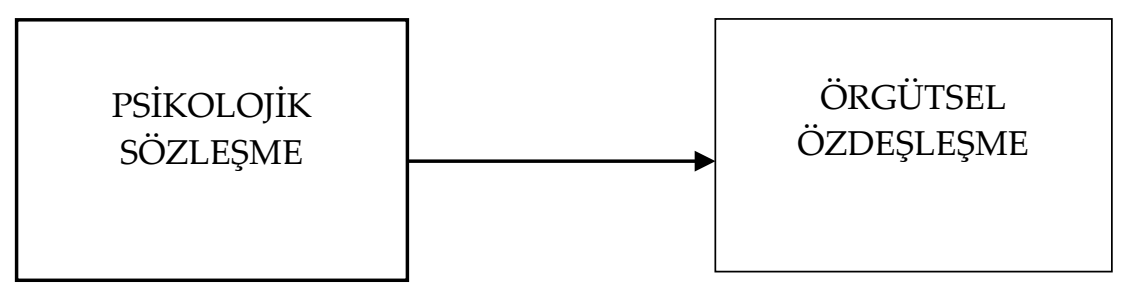

Şekil 1. Araştırmanın Modeli

H1: Psikolojik sözleşme ile örgütsel özdeşleşme arasında pozitif yönlü anlamlı bir ilişki vardir.

H2: İşlemsel psikolojik sözleşme cinsiyete göre anlamlı bir farklılık göstermektedir.

H3: İlişkisel psikolojik sözleşme cinsiyete göre anlamlı bir farklılık göstermektedir.

H4: Örgütsel özdeşleşme cinsiyete göre anlamlı farklılık göstermektedir.

H5: İşlemsel psikolojik sözleşme medeni duruma göre anlamlı bir farklılık göstermektedir.

H6: İlişkisel psikolojik sözleşme medeni duruma göre anlamlı bir farklılık göstermektedir.

H7: Örgütsel özdeşleşme medeni duruma göre anlamlı farklılık göstermektedir.

H8: İşlemsel psikolojik sözleşme yaşa göre anlamlı bir farklılık göstermektedir.

H9: İlişkisel psikolojik sözleşme yaşa göre anlamlı bir farklılık göstermektedir.

H10: Örgütsel özdeşleşme yaşa göre anlamlı farklılık göstermektedir.

H11: İşlemsel psikolojik sözleşme eğitim durumuna göre anlamlı bir farklılık göstermektedir.

H12: İlişkisel psikolojik sözleşme eğitim durumuna göre anlamlı bir farklılık göstermektedir.

H13: Örgütsel özdeşleşme eğitim durumuna göre anlamlı farklılık göstermektedir.

H14: İşlemsel psikolojik sözleşme kadro durumuna göre anlamlı bir farklılık göstermektedir.

H15: İlişkisel psikolojik sözleşme kadro durumuna göre anlamlı bir farklılık göstermektedir.

H16: Örgütsel özdeşleşme kadro durumuna göre anlamlı farklılık göstermektedir. 
H17: İşlemsel psikolojik sözleşme çalışma süresine göre anlamlı bir farklılık göstermektedir.

H18: İlişkisel psikolojik sözleşme çalışma süresine göre anlamlı bir farklılık göstermektedir.

H19: Örgütsel özdeşleşme çalışma süresine göre anlamlı farklılık göstermektedir.

\subsection{Verilerin Analizi}

Araştırmada kullanılan ölçeklerden ele edilen verilerin analizinde sosyal bilimler alanında yoğun olarak kullanılan veri analiz programı SPSS (22.0) (Statistical Package for Social Sciences) programı kullanılmıştır. Araştırma verilerinin normal dağılımını incelemek için yapılan testin sonucunda basıklık ve çarpıklık değerlerinin " +- 2" aralığında olduğu görülmüştür. Bu sonuç doğrultusunda parametrik analizlerin yapılması uygun görülmüştür (George ve Mallery, 2020: 114).

- $\quad$ Psikolojik sözleşme ile boyutlarının, örgütsel özdeşleşme ile ilişki düzeyini analiz etmek için Pearson Korelasyon analizi kullanılmıştır.

- Psikolojik sözleşme boyutları ile örgütsel özdeşleşmenin demografik faktörler açısından farklılıp gösterip göstermediğini analiz etmek için T-Testi, Tek Yönlü Varyans (Anova) testleri kullanılmıştır. Analiz sonuçlarında anlamlı bir farklılık görüldügünde farklılığın yönünü bulmak için Tukey HSD testinden yararlanılmıştır.

\subsection{Demografik Bulgular}

Araştırmada kullanılan demografik faktörler cinsiyet, yaş, medeni durum, eğitim, kadro ve çalışma süresinden oluşmaktadır.

Araştırmaya katılanların \%38,1'inin kadın, \%61,9'unun erkek olduğu, \%67,3'ünün evli, $\% 32,7^{\prime}$ sinin bekar, \%21,8'sinin 18-30, \%37,4'ünün 31-40 yaş aralığında ve \%40,8'inin 41 yaş ve üzerinde olduğu, \%20,4'ünün ilköğretim, \%34,7'sinin lise, \%16,3'ünün önlisans, \%28,6'sının lisans mezunu, \%33,3'ünün memur, \%66,7'sinin işçi kadrosunda olduğu, \%32 sinin 0-5 yıl aralığında, \%32,6'sının 6-15 yıl aralığında, \%35,4'ünün ise 16 yıl ve üzerinde çalışma süresine sahip olduğu görülmüş̧tür.

\subsection{Araştırmanın Tanımlayıcı İstatistikleri}

Araştırmada kullanılan ölçeklerin ve maddelerinin aritmetik ortalama değerleri ve standart sapmaları analiz edilmiştir. Psikolojik sözleşme ölçeğine ait tanımlayıcı analiz sonuçları Tablo 8' de gösterilmiştir.

Tablo 8. Psikolojik Sözleşme Ölçeğine Ait Tanımlayıcı İstatistikler

\begin{tabular}{lcc}
\hline Ölçek İfadeleri & $\begin{array}{c}\text { Aritmetik } \\
\text { Ortalama }\end{array}$ & $\begin{array}{c}\text { Standart } \\
\text { Sapma }\end{array}$ \\
\hline 1-İşimi sadece para için yapıyorum & 3,01 & 1,647 \\
\hline $\begin{array}{l}\text { 2-Kesin olarak belirlenmiş çalışma saatlerinde çalışmayı } \\
\text { tercih ederim }\end{array}$ & 3,98 & 1,337 \\
\hline 4-İşte her şeye karışmamak önemlidir & 3,44 & 1,429 \\
\hline 6-Her fazla mesai için ödeme yapılması beklentim var & 3,65 & 1,446 \\
\hline
\end{tabular}




\begin{tabular}{|c|c|c|}
\hline 7-İşe sadece işimi yapmak için geliyorum & 3,56 & 1,540 \\
\hline 11-Sadece işimin gereklerini yerine getiriyorum & 3,71 & 1,341 \\
\hline $\begin{array}{l}\text { 12-Gelecekte alacağım hak ve menfaatler (emeklilik, } \\
\text { sağlık güvencesi vb.) karşılığında bu kuruma \%100 } \\
\text { katkıda bulunmaya hazırım }\end{array}$ & 4,11 & 1,770 \\
\hline İşlemsel Psikolojik Sözleşme & 3,64 & 0,920 \\
\hline $\begin{array}{l}\text { 3-Hizmet sürem ve hedeflere ulaşmak için gösterdiğim } \\
\text { çaba karşıllı̆ında bu kurumda yükselmeyi bekliyorum }\end{array}$ & 3,35 & 1,565 \\
\hline 5-Şu an çalıştığım kurumda ilerlemeyi düşünüyorum & 3,14 & 1,493 \\
\hline $\begin{array}{l}\text { 8-Bu kurumda kendimi takımın bir parçası gibi } \\
\text { hissediyorum }\end{array}$ & 3,56 & 1,400 \\
\hline $\begin{array}{l}\text { 10-Bu kurumun, çalışanların emeklerinin karşılığını } \\
\text { verdiğini düşünüyorum }\end{array}$ & 3,20 & 1,353 \\
\hline $\begin{array}{l}\text { 13-Sıkı çalıştığım takdirde bu kurumda terfi edebilme } \\
\text { imkânım vardır }\end{array}$ & 2,63 & 1,443 \\
\hline $\begin{array}{l}\text { 14-Çalıştığım kurumda kariyer planım açık bir şekilde } \\
\text { belirlenmiştir }\end{array}$ & 2,71 & 1,260 \\
\hline 16-Bu kurumda sonuna kadar çalışırım & 3,33 & 1,341 \\
\hline İlişkisel Pskolojik Sözleşme & 3,20 & 1,057 \\
\hline
\end{tabular}

Psikolojik sözleşme ölçeğinin maddelerinin aritmetik ortalamalarına bakıldığında genel olarak aritmetik ortalamaların 3,00 ile 3,98 arasında olduğu görülmektedir. Bu sonuç ankete katılanların genellikle "Kararsızım" ile "Katılıyorum" arasında cevap verdiğini göstermektedir.

Fakat, 12'inci madde olan "Gelecekte alacağım hak ve menfaatler (emeklilik, sağlık güvencesi vb.) karşılığında bu kuruma \%100 katkıda bulunmaya hazırım” maddesinin aritmetik ortalaması $(\bar{x}=4,11)$ olarak görülmektedir. Bu sonuçta katılımcıların bu soruya daha çok "Katılıyorum" ile " Kesinlikle Katılıyorum" cevabını verdiğini göstermektedir. Bir başka madde olan "Sikı çalıştığım takdirde bu kurumda terfi edebilme imkânım vardır" ifadesine sahip $13^{\prime}$ üncü maddenin aritmetik ortalaması $(\overline{x=} 2,63)^{\prime}$ tür. Bu sonuç da katılımciların soruya genellikle "Katılmiyorum" ile "Kararsızım" arasında cevap verdiklerini göstermektedir.

Psikolojik sözleşme ölçeğinin boyutlarından olan işlemsel psikolojik sözleşmenin aritmetik ortalaması $(\bar{x}=3,64)$, ilişkisel psikolojik sözleşmenin aritmetik ortalaması ise $(\bar{x}=3,20)$ olarak belirlenmiştir. Buna göre katılımcıların işlemsel psikolojik sözleme algısının ilişkisel psikolojik sözleşme algısına göre daha yüksek görülmüştür. Örgütsel özdeşleşme ölçeğinin tanımlayıcı istatistiği ise aşağıdaki Tablo 9'da gösterilmiştir.

Tablo 9. Örgütsel Özdeleşme Ölçeğine Ait Tanımlayıcı İstatistikler 


\begin{tabular}{|c|c|c|}
\hline Ölçek İfadeleri & $\begin{array}{l}\text { Aritmetik } \\
\text { Ortalama }\end{array}$ & Standart Sapma \\
\hline $\begin{array}{l}\text { 1-Başka biri çalıştığım işletmeyi eleştirirse, } \\
\text { bunu kişisel hakaret olarak düşünürüm. }\end{array}$ & 3,20 & 1,332 \\
\hline $\begin{array}{l}\text { 2-Diğer insanların çalıştığım işletme } \\
\text { hakkındaki düşünceleri beni çok } \\
\text { ilgilendirir. }\end{array}$ & 3,51 & 1,289 \\
\hline 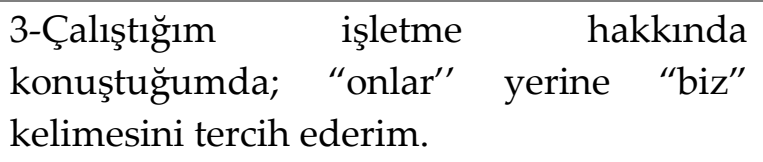 & 3,44 & 1,217 \\
\hline $\begin{array}{l}\text { 4-Çalıştığım işletmenin başarısı benim } \\
\text { başarımdır. }\end{array}$ & 3,61 & 1,150 \\
\hline $\begin{array}{l}\text { 5-Başka biri çalıştığım işletmeyi } \\
\text { övdüğünde, bunu kişisel iltifat olarak } \\
\text { düşünürüm. }\end{array}$ & 3,18 & 1,266 \\
\hline $\begin{array}{l}\text { 6-Medyada çalıştığım işletmeyle ilgili } \\
\text { olumsuzluklar oluşursa, rahatsızlık } \\
\text { hissederim. }\end{array}$ & 3,45 & 1,299 \\
\hline Örgütsel Özdeşleşme & 3,39 & 1,043 \\
\hline
\end{tabular}

Tablo 9'daki veriler incelendiğinde madde aritmetik ortalamalarının 3,18 ile 3,61 arasında olduğu görülmektedir. Bu sonuç katılımcıların sorulara daha çok "Kararsızım" ile "Katılıyorum" arasında cevap verdiğini göstermektedir. Örgütsel özdeşleşme ölçeğinin genel aritmetik ortalaması $(\bar{x}=3,39)$ olarak görülmektedir. $\mathrm{Bu}$ sonuç katılımcıların örgütleriyle daha çok orta düzeyde özdeşleştiklerini göstermektedir.

\subsection{Psikolojik Sözleşme ile Örgütsel Özdeşleşme İlişkisine Yönelik Korelasyon} Analizleri

Psikolojik sözleşme ve psikolojik sözleşme boyutları olan işlemsel psikolojik sözleşme ile ilişkisel psikolojik sözleşme boyutlarının örgütsel özdeşleşme ile olan ilişkilerini incelemek için korelasyon analizi yapılmıştır. Yapılan analiz sonuçları aşağıdaki Tablo 10'da gösterilmiştir.

Tablo 10. Araştırmaya İlişkin Korelasyon Analiz Sonuçları

\begin{tabular}{|c|c|c|c|}
\hline & & Psikolojik Sözleşme & Örgütsel Özdeşleşme \\
\hline \multirow{4}{*}{$\begin{array}{l}\text { Psikolojik } \\
\text { Sözleşme }\end{array}$} & Pearson & 1 & \\
\hline & Korelasyon & & \\
\hline & Sig. & & \\
\hline & $\mathrm{N}$ & 147 & \\
\hline Örgütsel & Pearson & $528^{* *}$ & 1 \\
\hline
\end{tabular}




\begin{tabular}{llll}
\hline Özdeşleşme & \multicolumn{2}{l}{ Korelasyon } & \\
\cline { 2 - 4 } & Sig. & & \\
& $\mathrm{N}$ & 147 & 147 \\
\hline
\end{tabular}

Hipotez doğrultusunda yapılan korelasyon analizi sonucunda psikolojik sözleşme ile örgütsel özdeşleşme arasında $(r=, 528)$ pozitif yönlü orta kuvvette anlamlı bir ilişki olduğu görülmektedir. Buna göre örgütlerde çalışanların psikolojik sözleşme alg1 düzeyleri yükseldikçe örgütle özdeşleşme düzeylerinin de arttığı söylenebilir. Bu sonuç doğrultusunda H1 hipotezi kabul edilmiştir.

\subsection{Bağımsız T-testi Analizleri}

Psikolojik sözleşmenin boyutları olan işlemsel psikolojik sözleşme ile ilişkisel psikolojik sözleşme boyutlarının ve örgütsel özdeşleşmenin, demografik faktörlerden olan cinsiyet, medeni durum ve kadro durumlarına göre anlamlı bir farklılık olup olmadığını analiz etmek için Bağımsız T-Testi analizi yapılmıştır. Bu kapsamda yapılan Bağımsız T-Testi analiz sonuçları tablolar halinde gösterilmiştir.

Tablo 12. Araştırmaya İlişkin Bağımsız T-Testi Analizi: Cinsiyet

\begin{tabular}{|c|c|c|c|c|c|c|c|}
\hline & Cinsiyet & $\mathbf{N}$ & Ortalama & $\begin{array}{l}\text { Standart } \\
\text { Sapma }\end{array}$ & $t$ & F & $\mathbf{P}$ \\
\hline \multirow{2}{*}{$\begin{array}{l}\text { İşlemsel } \\
\text { Psikolojik } \\
\text { Sözleşme }\end{array}$} & Kadın & 56 & 3,52 & 0,95 & \multirow[t]{2}{*}{$-1,240$} & \multirow[t]{2}{*}{0,420} & \multirow[t]{2}{*}{0,217} \\
\hline & Erkek & 91 & 3,71 & 0,90 & & & \\
\hline \multirow{2}{*}{$\begin{array}{l}\text { İlişkissel } \\
\text { Psikolojik } \\
\text { Sözleşne }\end{array}$} & Kadın & 56 & 3,15 & 1,01 & \multirow[t]{2}{*}{0,182} & \multirow[t]{2}{*}{2,257} & \multirow[t]{2}{*}{0,856} \\
\hline & Erkek & 91 & 3,12 & 1,10 & & & \\
\hline \multirow{2}{*}{$\begin{array}{l}\text { Örgütsel } \\
\text { Özdeşleşme }\end{array}$} & Kadın & 56 & 3,32 & 0,98 & \multirow[t]{2}{*}{$-0,751$} & \multirow[t]{2}{*}{0,702} & \multirow[t]{2}{*}{0,454} \\
\hline & Erkek & 91 & 3,45 & 1,08 & & & \\
\hline
\end{tabular}

Tablo 12'e göre, araştırmaya katılan erkek ve kadınların, işlemsel psikolojik sözleşme, ilişkisel psikolojik sözleşme ve örgütsel özdeşleşmeye göre anlamlı bir farklılık $(p>0,05)$ göstermemektedir. Bu analiz sonucunda $\mathrm{H} 2$, $\mathrm{H} 3$ ve $\mathrm{H} 4$ analizleri kabul edilmemiştir.

Tablo 13. Araştırmaya İlişkin Bağımsız T-Testi Analizi: Medeni Durum

\begin{tabular}{llcccccc}
\hline & Cinsiyet & N & Ortalama & $\begin{array}{c}\text { Standart } \\
\text { Sapma }\end{array}$ & T & F & P \\
\hline $\begin{array}{l}\text { İşlemsel } \\
\begin{array}{l}\text { Psikolojik } \\
\text { Sözleşme }\end{array}\end{array}$ & Evli & 99 & 3,53 & 1,01 & $-2,295$ & 17,148 & $\underline{\mathbf{0 , 0 2 3}}$ \\
\cline { 2 - 6 } & Bekar & 48 & 3,85 & 0,65 & & & \\
\hline
\end{tabular}




\begin{tabular}{|c|c|c|c|c|c|c|c|}
\hline \multirow{2}{*}{$\begin{array}{l}\text { İlişkissel } \\
\text { Psikolojik } \\
\text { Sözleşne }\end{array}$} & Evli & 99 & 3,05 & 1,06 & \multirow[t]{2}{*}{$-1,283$} & \multirow[t]{2}{*}{0,015} & \multirow[t]{2}{*}{0,202} \\
\hline & Bekar & 48 & 3,29 & 1,03 & & & \\
\hline \multirow{2}{*}{$\begin{array}{l}\text { Örgütsel } \\
\text { Özdeşleşme }\end{array}$} & Evli & 99 & 3,25 & 1,07 & \multirow[t]{2}{*}{$-2,251$} & \multirow[t]{2}{*}{4,200} & \multirow[t]{2}{*}{$\underline{0,012}$} \\
\hline & Bekar & 48 & 3,69 & 0,94 & & & \\
\hline
\end{tabular}

Tablo 13'ye göre, işlemsel psikolojik sözleşme açsısından araştırmaya katılanların medeni durumuna göre anlamlı bir farklılık $(p<0,05)$ görülmüsstür. Katılımcıların medeni durumlarının ortalamaları incelendiğinde araştırmaya katılanlardan bekar bireylerin $(3,85)$, evli bireylere $(3,53)$ göre işlemsel psikolojik sözleşme algısının yüksek olduğu görülmüştür. Bu sonuç doğrultusunda H5 hipotezi kabul edilmiştir. İlişkisel psikolojik sözleşme açısından araştırmaya katılanların medeni durumuna göre anlamlı bir farklılık $(\mathrm{p}>0,05)$ görülmemiştir. Bu sonuç doğrultusunda H6 hipotezi kabul edilmemiştir.

Örgütsel özdeşleşme açısından araştırmaya katılanların medeni durumuna göre anlamlı bir farklılık $(p<0,05)$ görülmüştür. Buna sonuca göre ortalamalara bakıldığında, bekar olan bireylerin $(3,69)$, evli olan bireylere göre $(3,25)$ özdeşleşme düzeyi yüksektir. Bu sonuç doğrultusunda $\mathrm{H7}$ hipotezi kabul edilmiştir.

Tablo 14. Araştırmaya İlişkin Bağımsız T-Testi Analizi: Kadro Durumu

\begin{tabular}{|c|c|c|c|c|c|c|c|}
\hline & $\begin{array}{l}\text { Kadro } \\
\text { Durumu }\end{array}$ & $\mathbf{N}$ & Ortalama & $\begin{array}{l}\text { Standart } \\
\text { Sapma }\end{array}$ & $t$ & F & $\mathbf{P}$ \\
\hline \multirow{2}{*}{$\begin{array}{l}\text { İşlemsel } \\
\text { Psikolojik } \\
\text { Sözleşme }\end{array}$} & Memur & 49 & 3,12 & 0,70 & \multirow[t]{2}{*}{$-5,698$} & \multirow[t]{2}{*}{4,191} & \multirow[t]{2}{*}{$\underline{0,000}$} \\
\hline & İşçi & 98 & 3,90 & 0,91 & & & \\
\hline \multirow{2}{*}{$\begin{array}{l}\text { İlişkissel } \\
\text { Psikolojik } \\
\text { Sözleşne }\end{array}$} & Memur & 49 & 3,63 & 1,10 & \multirow[t]{2}{*}{4,390} & \multirow[t]{2}{*}{0,325} & \multirow[t]{2}{*}{$\underline{0,000}$} \\
\hline & İşçi & 98 & 2,88 & 0,93 & & & \\
\hline \multirow{2}{*}{$\begin{array}{l}\text { Örgütsel } \\
\text { Özdeşleşme }\end{array}$} & Memur & 49 & 3,74 & 0,93 & \multirow[t]{2}{*}{2,925} & \multirow[t]{2}{*}{1,833} & \multirow[t]{2}{*}{$\underline{0,004}$} \\
\hline & İşçi & 98 & 3,22 & 1,06 & & & \\
\hline
\end{tabular}

Tablo 14 incelendiğinde işlemsel psikolojik sözleşme açısından araştırmaya katılan bireylerin kadro durumuna göre anlamlı bir farklılık $(p<0,05)$ görülmüştür. Buna göre, ortalamalara bakıldığında işçi kadrosuna sahip bireylerin $(3,90)$, memur kadrosuna sahip bireylere göre $(3,12)$ işlemsel psikolojik sözleşme algısının yüksek olduğu görülmektedir. Bu sonuç doğrultusunda H14 hipotezi kabul edilmiştir. İlişkisel psikolojik sözleşme açısından araştırmaya katılan bireylerin kadro durumuna göre anlamlı bir farklılık $(p<0,05)$ göstermektedir. Buna göre, ortalamalar incelendiğinde memur kadrosuna sahip bireylerin $(3,63)$, işçi kadrosuna sahip bireylere göre $(2,88)$ ilişkisel psikolojik sözleşme düzeylerinin yüksek olduğu görülmektedir. Bu sonuç doğrultusunda H15 hipotezi kabul edilmiştir. 
Örgütsel özdeşleşme açısından araştırmaya katılan bireylerin kadro durumuna göre anlamlı bir farklılık $(\mathrm{p}<0,05)$ görülmüştür. Buna göre, ortalamalara baktığımızda memur kadrosunda olan bireylerin $(3,74)$, işçi kadrosuna sahip bireylere göre $(3,22)$ örgütsel özdeşleşme düzeylerinin yüksek olduğu görülmektedir. Bu sonuç doğrultusunda H16 hipotezi kabul edilmiştir.

\subsection{Tek Yönlü Anova Analizi}

Araştırma kapsamında, psikolojik sözleşmenin alt boyutları olan işlemsel psikolojik sözleşme, ilişkisel psikolojik sözleşme ve örgütsel özdeşleşmenin, demografik faktörler olan eğitim, yaş ve çalışma sürelerine göre anlamlı bir farklılık olıp olmadığını analiz etmek amacı ile Tek Yönlü Anova analizi yapılmıştır. Analiz sonucunda anlamlı farklılığın çıkması durumunda, farklılığın yönünü bulmak için Poc Hoc analizlerinden olan Tukey HSD testi uygulanmıştır. Bu kapsamda yapılan analizler aşağıdaki tablolarda gösterilmiştir.

Tablo 15. Araştırmaya İlişkin Tek Yönlü Anova Analizi: Yaş

N Ortalama $\begin{gathered}\text { Standart } \\ \text { Sapma }\end{gathered} \quad$ F $\quad$ P

\begin{tabular}{|c|c|c|c|c|c|c|}
\hline \multirow{4}{*}{$\begin{array}{l}\text { İşlemsel } \\
\text { Psikolojik } \\
\text { Sözleşme }\end{array}$} & $18-30$ & 32 & 3,85 & ,71 & \multirow[t]{4}{*}{2,235} & \multirow[t]{4}{*}{ 111 } \\
\hline & $31-40$ & 55 & 3,71 & ,97 & & \\
\hline & 41 üzeri & 60 & 3,46 & ,95 & & \\
\hline & Toplam & 147 & 3,64 & ,92 & & \\
\hline \multirow{4}{*}{$\begin{array}{l}\text { İlişkisel } \\
\text { Psikolojik } \\
\text { Sözleşme }\end{array}$} & $18-30$ & 32 & 3,33 & 1,02 & \multirow[t]{4}{*}{1,287} & \multirow[t]{4}{*}{,279 } \\
\hline & $31-40$ & 55 & 3,18 & ,99 & & \\
\hline & 41 üzeri & 60 & 3,98 & 1,09 & & \\
\hline & Toplam & 147 & 3,13 & 1,04 & & \\
\hline \multirow{4}{*}{$\begin{array}{l}\text { Örgütsel } \\
\text { Özdeşleşme }\end{array}$} & $18-30$ & 32 & 3,52 & 1,12 & \multirow[t]{4}{*}{2,078} & \multirow[t]{4}{*}{, 129 } \\
\hline & $31-40$ & 55 & 3,55 & 89 & & \\
\hline & 41 üzeri & 60 & 3,19 & 1,11 & & \\
\hline & Toplam & 147 & 3,40 & 1,04 & & \\
\hline
\end{tabular}

Tablo 15 incelendiğinde, işlemsel psikolojik sözleşme, ilişkisel psikolojik sözleşme ve örgütsel özdeşleşme açısından araştırmaya katılanların yaş dağılımına göre anlamlı bir farklılık $(p>0,05)$ görülmemiştir. Bu netice doğrultusunda H8, H9, H10 hipotezleri kabul edilmemiştir.

Tablo 16. Araştırmaya İlişkin Tek Yönlü Anova Analizi: Eğitim Durumu

$\begin{array}{llll}\text { N Ortalama } & \begin{array}{c}\text { Standart } \\ \text { Sapma }\end{array} & \text { F } & \text { P }\end{array}$




\begin{tabular}{|c|c|c|c|c|c|c|}
\hline \multirow{5}{*}{$\begin{array}{l}\text { İşlemsel } \\
\text { Psikolojik } \\
\text { Sözleşme }\end{array}$} & İlköğretim & 30 & 3,94 & 1,20 & \multirow[t]{5}{*}{3,865} & \multirow[t]{5}{*}{011} \\
\hline & Lise & 51 & 3,81 & ,96 & & \\
\hline & Önlisans & 24 & 3,41 & ,66 & & \\
\hline & Lisans & 42 & 3,34 & ,63 & & \\
\hline & Toplam & 147 & 3,64 & 91 & & \\
\hline \multirow{5}{*}{$\begin{array}{l}\text { İlişkisel } \\
\text { Psikolojik } \\
\text { Sözleşme }\end{array}$} & İlköğretim & 30 & 2,46 & ,76 & \multirow[t]{5}{*}{15,163} & \multirow[t]{5}{*}{, 000} \\
\hline & Lise & 51 & 2,91 & ,98 & & \\
\hline & Önlisans & 24 & 3,16 & 1,07 & & \\
\hline & Lisans & 42 & 3,86 & 83 & & \\
\hline & Toplam & 147 & 3,13 & 1,03 & & \\
\hline \multirow{5}{*}{$\begin{array}{l}\text { Örgütsel } \\
\text { Özdeşleşme }\end{array}$} & İlköğretim & 30 & 2,82 & 1,24 & \multirow[t]{5}{*}{7,716} & \multirow[t]{5}{*}{000} \\
\hline & Lise & 51 & 3,25 & ,98 & & \\
\hline & Önlisans & 24 & 3,59 & ,99 & & \\
\hline & Lisans & 42 & 3,88 & ,71 & & \\
\hline & Toplam & 147 & 3,40 & 1,04 & & \\
\hline
\end{tabular}

Tablo 15 incelendiğinde işlemsel psikolojik sözleşme açısından araştırmaya katılan bireylerin eğitim durumuna göre anlamlı bir farklılık $(p<0,05)$ görülmüştür. Bu sonuca göre farklılığın yönünü bulmak adına yapılan analiz sonucunda ilköğretim eğitimi alan bireylerin, lisans eğitimi alan bireylere göre işlemsel psikolojik sözleşme algısının anlamlı düzeyde daha fazla olduğu görülmüştür. Bu sonuç doğrultusunda H11 hipotezi kabul edilmiştir. İlişkisel psikolojik sözleşme açısından araştırmaya katılan bireylerin eğitim durumuna göre anlamlı bir farklılık $(\mathrm{p}<0,05)$ görülmüştür. Bu sonuca göre farklılığın yönünü bulmak adına yapılan analizler doğrultusunda lisans eğitimi alan bireylerin, diğer eğitim düzeyde olan bireylere göre ilişkisel psikolojik sözleşme algıları anlamlı düzeyde daha fazladır. Bunun yanında önlisans eğitimi alan bireylerin lise ve ilköğretim eğitimi alan bireylere göre ilişkisel psikolojik sözleşme düzeyleri anlamlı derecede daha fazla olduğu görülmüştür. Bu sonuç doğrultusunda $\mathrm{H} 12$ hipotezi kabul edilmiştir.

Örgütsel özdeşleşme açısından araştırmaya katılanların eğitim durumlarına göre anlamlı bir farklılık $(p<0,05)$ görülmüştür. Bu sonuca göre farklılığın yönünü bulmak için yapılan analiz doğrultusunda lisans eğitimi alan bireylerin, lise ve ilköğretim eğitimi alan bireylere göre örgütsel özdeşleşme düzeyleri anlamlı düzeyde daha fazla olduğu görülmüştür. Bunun yanı sıra önlisans eğitimi alan bireylerin, ilköğretim eğitimi alan bireylere göre örgütsel özdeşleşme düzeyi anlamlı derecede daha fazla olduğu görülmüştür. Bu sonuç doğrultusunda $\mathrm{H} 13$ hipotezi kabul edilmiştir.

Tablo 17. Araştırmaya İlişkin Tek Yönlü Anova Analizi: Çalışma Süresi 


\begin{tabular}{|c|c|c|c|c|c|c|}
\hline & & $\mathbf{N}$ & Ortalama & $\begin{array}{l}\text { Standart } \\
\text { Sapma }\end{array}$ & $\mathbf{F}$ & $\mathrm{p}$ \\
\hline \multirow{4}{*}{$\begin{array}{l}\text { İşlemsel } \\
\text { Psikolojik } \\
\text { Sözleşme }\end{array}$} & $0-5 \mathrm{y} 1 \mathrm{l}$ & 47 & 3,74 & 88 & \multirow[t]{4}{*}{3,268} & \multirow[t]{4}{*}{041} \\
\hline & $6-15$ y1l & 48 & 3,81 & 86 & & \\
\hline & 16 y1l üzeri & 52 & 3,38 & 97 & & \\
\hline & Toplam & 147 & 3,64 & ,92 & & \\
\hline \multirow{4}{*}{$\begin{array}{l}\text { İlişkisel } \\
\text { Psikolojik } \\
\text { Sözleşme }\end{array}$} & $0-5$ y1l & 47 & 3,15 & ,97 & \multirow[t]{4}{*}{,209 } & \multirow[t]{4}{*}{811} \\
\hline & $6-15$ y1l & 48 & 3,20 & 1,07 & & \\
\hline & 16 yil üzeri & 52 & 3,06 & 1,13 & & \\
\hline & Toplam & 147 & 3,13 & 1,06 & & \\
\hline \multirow{4}{*}{$\begin{array}{l}\text { Örgütsel } \\
\text { Özdeşleşme }\end{array}$} & $0-5$ yil & 47 & 3,35 & 1,10 & \multirow[t]{4}{*}{2,049} & \multirow[t]{4}{*}{ 133 } \\
\hline & $6-15$ y1l & 48 & 3,64 & 89 & & \\
\hline & 16 yil üzeri & 52 & 3,22 & 1,09 & & \\
\hline & Toplam & 147 & 3,40 & 1,04 & & \\
\hline
\end{tabular}

Tablo 17 incelendiğinde, işlemsel psikolojik sözleşme açısıdan araştırmaya katılan bireylerin çalışma sürelerine göre anlamlı bir farklılık $(p<0,05)$ görülrmüştür. Bu sonuç doğrultusunda farklılığın yönünü bulmak için yapılan analize göre 6-15 yıl aralığında çalışan bireylerin, 16 yıl ve üzeri aralığında çalışan bireylere göre işlemsel psikolojik sözleşme düzeyleri anlamlı derecede daha fazla olduğu görülmüştür. Bu sonuca göre $\mathrm{H} 17$ hipotezi kabul edilmiştir. İlişkisel psikolojik sözleşme araştırmaya katılan bireylerin çalışma sürelerine göre anlamlı bir farklılık $(p>0,05)$ göstermemektedir. Bu sonuç doğrultusunda H18 hipotezi kabul edilmemiştir.

Örgütsel özdeşleşme araştırmaya katılan bireylerin çalışma sürelerine göre anlamlı bir farklılık $(p>0,05)$ göstermemektedir. Bu sonuç doğrultusunda H19 hipotezi kabul edilmemiştir.

\subsection{Araştırmanın Hipotez Tablosu}

Çalışma kapsamında yapılan istatistiki analizlerin sonucunda kabul edilen ve reddedilen hipotezler aşağıdaki Tablo 18'de gösterilmiştir.

Tablo 18. Hipotez Kabul/Ret Tablosu

\begin{tabular}{|l|l|c|}
\hline & \multicolumn{1}{|c|}{ HİPOTEZLER } & KABUL/RET \\
\hline H1 & $\begin{array}{l}\text { Psikolojik sözleşme ile örgütsel özdeşleşme arasında } \\
\text { pozitif yönlü anlamlı bir ilişki vardır. }\end{array}$ & Kabul \\
\hline H2 & $\begin{array}{l}\text { İşlemsel psikolojik sözleşme cinsiyete göre anlamlı bir } \\
\text { farklılık göstermektedir. }\end{array}$ & Ret \\
\hline
\end{tabular}




\begin{tabular}{|c|c|c|}
\hline $\mathrm{H} 3$ & $\begin{array}{l}\text { İlişkisel psikolojik sözleşme cinsiyete göre anlamlı bir } \\
\text { farklılık göstermektedir. }\end{array}$ & Ret \\
\hline $\mathrm{H} 4$ & $\begin{array}{l}\text { Örgütsel özdeşleşme cinsiyete göre anlamlı farklılık } \\
\text { göstermektedir. }\end{array}$ & Ret \\
\hline H5 & $\begin{array}{l}\text { İşlemsel psikolojik sözleşme medeni duruma göre } \\
\text { anlamlı bir farklılık göstermektedir. }\end{array}$ & Kabul \\
\hline H6 & $\begin{array}{l}\text { İlişkisel psikolojik sözleşme medeni duruma göre } \\
\text { anlamlı bir farklılık göstermektedir. }\end{array}$ & Ret \\
\hline $\mathrm{H} 7$ & $\begin{array}{l}\text { Örgütsel özdeşleşme medeni duruma göre anlamlı } \\
\text { farklılık göstermektedir. }\end{array}$ & Kabul \\
\hline $\mathrm{H} 8$ & $\begin{array}{l}\text { İşlemsel psikolojik sözleşme yaşa göre anlamlı bir } \\
\text { farklılık göstermektedir. }\end{array}$ & Ret \\
\hline H9 & $\begin{array}{l}\text { İlişkisel psikolojik sözleşme yaşa göre anlamlı bir } \\
\text { farklılık göstermektedir. }\end{array}$ & Ret \\
\hline H10 & $\begin{array}{l}\text { Örgütsel özdeşleşme yaşa göre anlamlı farklılık } \\
\text { göstermektedir. }\end{array}$ & Ret \\
\hline H11 & $\begin{array}{l}\text { İşlemsel psikolojik sözleşme eğitim durumuna göre } \\
\text { anlamlı bir farklılık göstermektedir. }\end{array}$ & Kabul \\
\hline H12 & $\begin{array}{l}\text { İlişkisel psikolojik sözleşme eğitim durumuna göre } \\
\text { anlamlı bir farklılık göstermektedir. }\end{array}$ & Kabul \\
\hline H13 & $\begin{array}{l}\text { Örgütsel özdeşleşme eğitim durumuna göre anlamlı } \\
\text { farklılık göstermektedir. }\end{array}$ & Kabul \\
\hline H14 & $\begin{array}{l}\text { İşlemsel psikolojik sözleşme kadro durumuna göre } \\
\text { anlamlı bir farklılık göstermektedir. }\end{array}$ & Kabul \\
\hline H15 & $\begin{array}{l}\text { İlişkisel psikolojik sözleşme kadro durumuna göre } \\
\text { anlamlı bir farklılık göstermektedir. }\end{array}$ & Kabul \\
\hline H16 & $\begin{array}{l}\text { Örgütsel özdeşleşme kadro durumuna göre anlamlı } \\
\text { farklılık göstermektedir. }\end{array}$ & Kabul \\
\hline H17 & $\begin{array}{l}\text { İşlemsel psikolojik sözleşme çalışma süresine göre } \\
\text { anlamlı bir farklılık göstermektedir. }\end{array}$ & Kabul \\
\hline H18 & $\begin{array}{l}\text { İlişkisel psikolojik sözleşme çalışma süresine göre } \\
\text { anlamlı bir farklılık göstermektedir. }\end{array}$ & Ret \\
\hline H19 & $\begin{array}{l}\text { Örgütsel özdeşleşme çalışma süresine göre anlamlı } \\
\text { farklılık göstermektedir. }\end{array}$ & Ret \\
\hline
\end{tabular}




\section{SONUÇ VE DEĞERLENDİRME}

Psikolojik sözleşme kavramı, işveren ile işgören arasında yapılan iş sözleşmelerindeki boşlukları dolduran ve taraflar arasındaki beklentilere cevap veren bir kavram olarak ortaya çıkmaktadır. İşletmelerde işveren ile işgörenlerin, psikolojik sözleşmenin yükümlülüklerini yerine getirmesi halinde daha verimli hizmet ve üretim ortaya çıacaktır. İşverenin, psikolojik sözleşmeyi bozmaması durumunda, işgörenlerin işletmeye daha çok bağlanmaları hatta işletme ile kendilerini özdeşleştirmeleri beklenmektedir. Örgütsel özdeşleşme kavramı kısaca, çalışanın kendisini, örgüt ile bir bütün halinde görmesi olarak tanımlanır. Bu durumda işgörenin, işletmeye karşı kendini daha çok sorumlu hissederek, daha fazla çaba sarf etmesi beklenmektedir.

Araştırma kapsamında yapılan tanımlayıcı istatistikler, psikolojik sözleşme kavramının boyutları ile örgütsel özdeşleşme üzerinde incelenmiştir. Bu doğrultuda, psikolojik sözleşme boyutlarından, işlemsel psikolojik sözleşme boyutunun aritmetik ortalaması 3,64 ve diğer boyutu olan ilişkisel psikolojik sözleşme boyutunun ortalaması ise 3,20 olarak görülmüştür. İşlemsel psikolojik sözleşme boyutunun aritmetik ortalamasının, ilişkisel psikolojik sözleşme boyutunun aritmetik ortalamasından büyük olması personelin sözleşmeye daha çok maddi yönden yaklaştığı şeklinde açıklanabilir. Bu sonuç doğrultusunda personel görev ve sorumluluklarını yerine getirirken daha az performans ve verimlilik göstereceklerdir. Örgüt, personelin ilişkisel sözleşme algısını artırmaya yönelik çalışmalar yaparak personelin sadece sözleşmeye maddi açıdan değil, manevi açıdan da yaklaşmalarını sağlayarak daha yüksek düzeyde performans ve verimlilik elde edebilir. Böylece personel, örgüt ile daha fazla özdeşleşme gösterebilecektir.

Yapılan korelasyon analizi sonucunda, psikolojik sözleşme ile örgütsel özdeşleşme arasında pozitif yönlü orta kuvvette anlamlı bir ilişki görülmüştür. Buna göre, belediye personelinin psikolojik sözleşme algısı artıkça, örgütsel özdeşleşme düzeylerinin de artacağ görülmektedir. Yapılan analiz sonucunda belediye örgütünün, psikolojik sözleşme kavramına önem vermesi ve psikolojik sözleşmenin meydana getirdiği yükümlülükleri yerine getirmesi gerektiğinin önemi görülmektedir. Belediye psikolojik sözleşme yükümlülüklerine yerine getirdiğinde, personelde kendini sorumlu hissederek kendi yükümlülüklerini yerine getirerek psikolojik sözleşmenin yerine getirilmesi sağlayacaktır. Psikolojik sözleşmenin yükümlülüklerinin yerine getirilmesi, personelin örgüte karşı daha fazla bağlılık ve güven duymasına neden olarak kurumu ile özdeşleşme düzeyini arttıracaktır. Belediye ile özdeşleşme düzeyi artan personel, belediyenin hizmetlerini yerine getirirken daha etkin ve verimli bir şekilde çalışacaktır. Böylece, belediye sorumlusu olduğu vatandaşa karşı güven kazanarak, istikrarlı bir yönetim ortaya çıkaracaklardır. Bu sebeplerden, belediye örgüt çalışanlarının psikolojik sözleşme algı düzeylerini arttırmaya yönelik sözleşme gerekliliklerini yerine getirme, eğitim ve kariyer olanaklarının geliştirilmesi gibi birtakım çalışmalar yapması gerektiği söylenebilir.

Medeni durumu bekar olan personelin işlemsel psikolojik sözleşme algısının anlamlı düzeyde daha fazla olması, bu çalışanların işi bırakma, değiştirme kararlarını evli olan çalışanlara göre daha rahat alabilme olasılığından kaynaklandığı söylenebilir. Örgütün kariyer, terfi gibi olanaklarının kısıntılı olması bekar çalışanların örgütle olan ilişkisini kısa ömürlü görmelerine neden olabilir. Örgütün bekar olan çalışanların ilişkisel sözleşme 
algılarını yükseltmek için çalışmalar yapması gerektiği görülmektedir. Bekar olan çalışanların genellikle ilk iş deneyiminin olması ve kamu kuruluşlarının, özel kuruluşlara göre daha güvenceleri görmeleri kurumla başlarda özdeşleşme düzeylerinin yüksek almasına sebep olduğu söylenebilir. Fakat evli olan çalışanların, bekar olan çalışanlara göre anlamlı düzeyde daha az özdeşleştikleri göz önüne alınırsa, ilerleyen zamanda bekar çalışanların özdeşleşme düzeylerinde azalma gerçekleşebilir. Örgüt, olası bu durumların önüne geçmek ve mevcut durumdaki çalışanların özdeşleşme düzeylerini artırmaya yönelik çalışmalar yapması gerekmektedir.

Örgütte, memur kadrosunda çalışan çalışanların, işçi kadrosundaki çalışanlara göre daha güvenceli kadroya sahip olmaları, maddiyat, terfi ve kariyer gibi olanaklarının daha iyi olaması memur kadrosundanki çalışanların ilişkisel psikolojik sözleşme algılarının anlamlı düzeyde yüksek olmasına neden olduğu söylenebilir. Aynı sebeplerden dolayı memur kadrosundaki çalışanların özdeşleşme düzeylerinin aynı doğrultuda anlamlı düzeyde yüksek çıkmasına neden olduğu söylenebilir. Örgüt bu kapsamda, farklı kadrolardaki çalışanların olanaklarının dengeli bir hale getirerek, çalışanların psikolojik sözleşme algılarını ve özdeşleşme düzeylerini artırmak için çalışmaları yapması gerekmektedir. Böylelikle çalışanlarında aynı düzeyde performans ve verimlilik sağlayabilir.

Örgütte çalışanların çalışma sürelerinin arttıkça işlemsel psikolojik sözleşme alg1 düzeylerinin anlamlı düzeyde azalması, çalışanların örgütten ayrılma, iş değiştirme gibi olanaklarının zaman geçtikçe azalması çalışanların artık örgüte daha fazla bağlanmalarına ve sorumluluklarını daha iyi yerine getirerek örgütteki yerlerini daha fazla korunma isteğiyle açıklanabilir. Fakat örgüt, daha iyi hizmet sunmak için çalışanlarının zaman içinde bu algının yerleşmesi beklemeleri örgütün güven ve istikrarının oluşmasını önemli ölçüde etkileyecektir. Örgüt bu algının oluşmasını en kısa sürede sağlaması gerekmektedir. Böylece örgüt daha fazla güven ve istikrar sağlayacaktır.

Eğitim düzeyi lisans seviyesindeki olan çalışanların, diğer eğitim seviyesine sahip çalışanlara göre ilişkisel psikolojik sözleşme algıları anlamlı düzeyde farklılık göstermesi ve daha yüksek seviyede örgütle özdeşleşmesi çalışanların eğitim düzeyinin önemini göstermektedir. Eğitim düzeyi artan çalışanların, örgüt yapılarına, işleyişine ve kavramlarına hakim olması psikolojik sözleşme ve özdeşleşme düzeylerinin artmasına sebep olduğu söylenebilir. Çalışmanın sonucu yapılan analiz doğrultusunda, örgütün çalışanların eğitimine önem vermesi gerektiği görülmektedir. Örgüt bu kapsamda, çalışanların eğitim düzeylerini artması için çeşitli teşvik ve çalışmalar yapması gerekmektedir.

Genel olarak özetlenecek olursa, belediyeler ülkenin idari yapısındaki yerinden yönetim teşkilatları içerisinde yer alan mahalli idare kuruluşlarıdır. Belediyeler, halka hizmet götüren en yakın kamu kuruluşlarındadır. Belediye teşkilatı içindeki yöneticiler seçimle iş başına gelmektedir. Bu kapsamda seçimle iş başına gelen idarecilerin yönetimde istikrar sağlamak için hizmet verdikleri halka karşı güven sağlamaları gerekmektedir. Belediyeler, halka karşı yaptıkları hizmetleri bünyesinde yer alan çalışanları aracılığıyla gerçekleştirmektedir. Bu sebepten dolayı çalışanların, belediye ve halka karşı tutum ve davranışları önem arz etmektedir. Belediyeler, bünyelerinde görev yapan personelin beklentilerini ne kadar çok karşılarsa aynı oranda personel sorumluluk hissederek aynı şekilde belediyenin bekletilerini karşılayacaktır. Psikolojik sözleşme kavramı burada önemli bir kavram olarak öne 
çıkmaktadır. Psikolojik sözleşme algısı yükselen çalışanların belediye ile özdeşleşme düzeyleri de artacaktır. Böylece çalışanlar yaptıkları her işte kendilerini belediye ile bir bütün görerek işlerini en iyi şekilde yerine getireceklerdir. Belediye çalışanları, halka karşı hizmet verirken en iyi şekilde ve en kısa sürede halkın beklentisi yerine getirmesi, halk tarafından belediyeye karşı güven ortamı oluşturacaktır. Bu durum, belediyenin istikrarlı olarak devam etmesini sağlayacaktır. Bu sebeplerden dolayı belediye kuruluşlarının psikolojik sözleşme ve örgütsel özdeşleşme kavramlarına önem vermeleri ve bu kavramların kurum içerisinde yerleşmesine yönelik çalışmalar gerçekleştirmeleri gerekmektedir. Belediyenin yapması gereken çalışmalar için birtakım öneriler madde halinde aşağıda belirtilmiştir.

- $\quad$ Örgüt ile personel arasında yapılan sözleşme gereklerini yerine getirmelidir.

- $\quad$ Personelin gelişimi için eğitim çalışmaları yapmalıdır.

- $\quad$ Personelin görev tanımı açıkça tanımlanmalıdır.

- $\quad$ Personelin sosyal güvencelerini en iyi şekilde sağlamalıdır.

- $\quad$ Personelin kariyer olanakları net bir şekilde belirtilmelidir.

- $\quad$ Personel çalışma ve güvenlik ortamı en iyi şekilde sağlamalıdır.

- $\quad$ Personelin ücret düzeyi adaletli bir şekilde belirlenmeli ve ücretler zamanında yatırılmalıdır.

- $\quad$ Personel için danışma hizmetleri verilmelidir.

Bundan sonraki araştırmalarda, psikolojik sözleşme ile örgütsel özdeşleşme arasındaki ilişkiyi daha iyi analiz etmek için örneklem sayısının artırılması ya da farklı gruplar üzerinde çalışılıp, sonuçların karşılaştırılması ile daha iyi sonuçlar ortaya konulabilir.

\section{KAYNAKÇA}

Anderson, N. and Schalk, R. (1998). “The Psychological Contract in Retrospect and Prospect, Goldsmiths College", University of London, Journal of Organizational Behavior, 19, 637647.

Arnold, John (1996), "The Psychological Contract: A Concept in Need of Closer Scrunity?", European Journal of Work and Organizational Psychology, 5/4, 511-520.

Albert, S., Ashforth, B.E. and J.E. Dutton (2000). "Organizational Identity and Identification: Charting New Waters and Building New Bridges", Academy of Management Journal, 25/1, 13-17.

Boroş, S. (2008). "Organizational Identification: Theoretical and Empirical Analyses of Competing Conceptualizations", Cogniție, Creier, Comportament / Cognition, Brain, Behavior. XII/1, 1-27.

Carmeli, A., Gilat, G. and Waldman, D. A. (2007). “The role of perceived organizational performance in organizational identification, adjustment and job performance", Journal of Management Studies, 5, 1-21. 
CIPD (2010). The Psychological Conract Report, http://www.cipd.co.uk/subjects/empreltns/psycntrct/psycontr.htm?wa_src=email\&wa _pub=cipd\&wa_crt=feature3_main_none\&wa_cmp=cipdupdate_160610, (19.12.2019).

Cihangiroğlu, N. ve Şahin, B. (2010). “Organizasyonlarda Önemli Bir Fenomen: Psikolojik Sözleşme”, ZKÜ Sosyal Bilimler Dergisi, 6/11, 1-16.

Coyle-Shapiro, J. A. and Kessler, I. (2000). "Consequences of the Psychological Contract For The Employment Relationship: A Large Scale Survey", Journal of Management Studies, 37/7, 903-930.

Cohen, L., Manion, L. and Morrison, K. (2000). Research Methods in Education, (5th Edition), Routledge Falmer, London.

Demiral, Ö. (2008). Örgütsel Bağhlı̆̆ın Sağlanmasında Personel Güçlendirme ve Psikolojik Sözleşmenin Etkisine İlişkin Bir Araştırma. (Yüksek Lisans Tezi), Niğde Üniversitesi Sosyal Bilimler Enstitüsü, İşletme Anabilim Dalı, Niğge.

Dikili, A. (2012). Psikolojik Sözleşme ile İş Tatmini Illişkisi: Bir Örnek Olay Çalışması, (Doktora Tezi), Sakarya Üniversitesi, Sosyal Bilimler Enstitüsü, İşletme Anabilim Dalı, Yönetim ve Organizasyon Bilim Dalı, Sakarya.

Dutton, J.E., Dukerich, J.M. and Harquail, C.V. (1994). “Organisational images and member identification", Administration Science Quarterly, 39, 239- 263.

Envergil, D. (2018). Psikolojik Sözleşme Algılarının Örgütsel Güven, Örgütsel Özdeşleşme ve Örgütsel Vatandaşlık Davranışı Üzerindeki Etkileri, Hacettepe Üniversitesi, Sosyal Bilimler Enstitüsü, Sağlık Yönetimi Anabilim Dalı, Ankara.

Eroğlu F., Eroğlu G.Ş. ve Enli P. (2015). “Yönetilenler ve Yöneticiler Açısından Örgütsel Özdeşleşme ve Örgütsel Tutarsızlık Hakkında Bir Araştırma", 23.Ulusal Yönetim ve Organizasyon Kongresi, 1017-1024.

Gautam, T., Van Dick, R., and Wagner, U., (2004). “Organizational identification and organizational commitment: Distinct aspects of two related concepts", Asian Journal of Social Psychology, 7, 301-315.

George, D. and Mallery, P. (2010). IBM SPSS Statistics 23 Step by Step: A Simple Guide and Reference, (14th Edition), Pearson Education, New York.

Gossett, L. (2002). “Kept at arm's length: Questioning the organizational desirability of member identification", Communication Monographs, 69/4, 385-404.

Hui, C., Lee, C. and Rousseau, D. M. (2004). "Psychological Contract and Organizational Citizenship Behavior in China: Investigating Generalizability and Instrumentality", Journal of Applied Psychology, 89/2, 311-321.

Hess, N. and Jepsen, D. M. (2009). "Career Stage and Generational Differences in Psychological Challenge Consulting", Career Development International, 14/3, 261-283.

İyigün, N. Ö. ve Çetin, C. (2012). “Psikolojik Kontratın Örgütsel Sapma Üzerindeki Etkisi ve İlaç Sektöründe Bir Araştırma", Öneri Dergisi, 10, 15-29. 
Kıyık, G. (2011). Psikolojik Sözleşme Kavramının, Türkiye'de Sektörü Üzerindeki Etkisinin İncelenmesi ve Analizi, (Doktora Tezi), Anadolu Üniversitesi, Sosyal Bilimler Enstitüsü, İşletme Anabilim Dalı, Yönetim ve Organizasyon Bilim Dalı, Eskişehir.

Karabulut, M. (2019). Türkiye Yerel Yönetimlerinde Örgütsel Güven, Örgütsel Özdeşleşme ve İş Tatmini İlişiği: Elazı̆̆ Belediyesi, (Yüksek Lisans Tezi), Ardahan Üniversitesi, Sosyal Bilimler Enstitüsü, Siyaset Bilimi Ve Kamu Yönetimi Anabilim Dalı, Ardahan.

Karcıŏglu, F. ve Türker, E. (2010). “Psikolojik Sözleşme ile Örgütsel Bağlılık İlişkisi:

Sağlık Çalışanları Üzerine Bir Araştırma”, Atatürk Üniversitesi İktisadi ve İdari

Bilimler Dergisi, 24/2, 121-140.

Kızıl, S. (2016). Yöneticilerin Stratejik Liderlik Davranışlarının Kurumsal İtibar Algısı Üzerine Etkisinde Örgütsel Özdeşleşmenin Ve Kurumsal Sosyal Sorumluluğun Rolü, (Yüksek Lisans Tezi), Atatürk Üniversitesi, Sosyal Bilimler Enstitüsü, İşletme Anabilim Dalı, Erzurum.

Koyuncu, H. (2019). Psikolojık Sözleşme İhlalinin Örgütsel Güven ve Örgütsel Özdeşleşme Üzerıne Etkısı: Karabük Ünıversıtesınde Bır Uygulama, (Yüksek Lisans Tezi), Karabük Üniversitesi, Sosyal Bilimler Enstitüsü, İşletme Anabilim Dalı, Karabük.

Köse, C.G., (2009), Örgütsel Özdeşleşmenin Çalışanların Sürekli İyileştirme Çabalarına Katkısı: Bir Araştırma, (Yüksek Lisans Tezi), İstanbul Üniversitesi Sosyal Bilimler Enstitüsü, İşletme Anabilim Dalı, İşletme Yönetimi ve Organizasyon Bilim Dalı, İstanbul.

Mael, F. and Ashforth, B. E. (1992). “Alumni and Their Alma Mater: A Partial Test of The Reformulated Model of Organizational Identification", Journal of Organizational Behavior, 13/2, 103-123.

McDonald, D. J. and Makin, P. J. (2000). “The Psychological Contract, Organisational Commitment and Job Satisfaction of Temporary Staff", Leadership E Organization Development Journal, 21/2, 84-91.

Millward, L. J. ve Hopkins, L. J. (1998). "Psychological Contracts, Organizational and Job Commitment", Journal of Applied Social Psychology, 28/16, 1530-1556.

Morrison, D. E. (1994). "Psychological Contracts \& Change", Human Resource Management, $33 / 3,353-372$.

Morrison, E. W. and Robinson, S. L. (1997). “When Employees Feel Betrayed: A Model of How Psychological Contract Violation Develops", Academy of Management Review, 22/1, 226-256.

Özler, E., ve Ünver, E. (2012). “Psikolojik Sözleşmenin İş Tatmini Üzerindeki Etkisini Belirlemeye Yönelik Bir Araştırma", Süleyman Demirel Üniversitesi İktisadi ve İdari Bilimler Fakültesi Dergisi, 17/2, 325-351.

Petersitzke, M. (2009). Supervisor Psychological Contract Management, Gabler Edition Wissenschaft, Hamburg.

Riketta, M. (2005). “Organizational Identification: A Meta-Analysis\|”, Journal of Vocational Behavior, 66, 358-384. 
Robinson S. L., Kraatz, M. S. and Rousseau D. M. (1994). "Northwestern University Changing Obligations And The Psychological Contract: A Longitudinal Study" Academy Of Management Journal, 37/1, 137-152.

Rousseau, D. (1995). Psychological Contracts in Organizations: Understanding Written and Unwritten Agreements. Sage Publications, USA.

Rousseau, D.M. (1990), “New hire perceptions of their own and their employer's obligations: a study of psychological contracts," Journal of Organizational Behavior, 11, 389-400.

Rousseau, D. M. (2004). "Psychological Cotracts İn The Workplace: Understanding The Ties That Motivate", Academy Of Management Executive, 18/1, 120-125.

Rousseau, D. M. and Schalk, R. (2000). Psychological Contracts in Employment: Cross-National Perspectives. CA: Sage, in Pres, Newbury Park.

Rousseau, D. M. and Tijoriwala, S. A. (1998). “Assessing Psychological Contracts: Issues, Alternatives, and Types of Measures", Journal of Organizational Behavior, 19, 679695.

Rousseau, D. M. and Wade-Benzoni, K. A. (1994). "Linking Strategy and Human Resource Practices: How Employee And Customer Contracts are Created", Human Resource Management, 33, 463-489.

Schein, E. H. (1978). Örgüt Psikolojisi, Çeviren: Mustafa Tosun, Türkiye Ve Orta Doğu Amme İdaresi Enstitüsü, Ankara.

Sels, L., Janssens, M. and Van Den Brande I. (2004). “Assessing the Nature of Psychological Contracts: A Validation of Six Dimensions", Journal of Organizational Behavior, 25/4, 461-488.

Serinkan, C. ve Tülü, M. (2021). “Örgütsel Özdeşleşme ve Örgütsel Sinizm İlişkisi: Pamukkale Üniversitesindeki İdari Personele Yönelik Bir Araştırma”, İktisadi İdari Ve Siyasal Araştırmalar Dergisi, 6/14, 48-70.

Solnet, D., (2006). “Introducing Employee Social Identification To Customer Satisfaction Research A Hotel Industry Study", Managing Service Quality, 16/6, 575-594.

Sökmen, A., Ekmekçioğlu, E. B. ve Çelik, K. (2015). “Algılanan Örgütsel Destek, Örgütsel Özdeşleşme ve Yönetici Etik Davranışı İlişkisi: Araştırma Görevlilerine Yönelik Araştırma", İşletme Araştırmaları Dergisi, 7/1, 125-144.

Yıldız, H., Yıldız, B. ve İyigün, N. Ö. (2016). “Psikolojik Sözleşme Algısının Sanal Kaytarma Davranışları Üzerindeki Etkisi”, Erciyes Üniversitesi İktisadi ve İdari Bilimler Fakültesi Dergisi, 47, 147-165.

Topcu, K. M. (2015). Çalışanların Kişilik Özelliklerinin Örgütsel Özdeşleşme ve İşten Ayrılma Niyeti Üzerine Etkisinde Psikolojik Sözleşme Algısının Rolü, (Doktora Tezi), Kara Harp Okulu Savunma Bilimleri Enstitüsü, Savunma Yönetimi Anabilim Dalı, Ankara.

Topaloğlu, H. ve Arastaman, G. (2016). “Örgütlerde Psikolojik Sözleşme Üzerine Kuramsal Bir Değerlendirme”", Ihlara Ĕ̆itim Araştırmaları Dergisi. 1/2, 25-36. 
Kotter, J. (1973). "Psychological Contract: Managing the Joining-Up Process", California Management Review, XV/3, 91-99.

Tolman, E. C. (1943). "Identification and The post-war world”, Psychological Review, 38/1, 141148.

Topçu, M. K. ve Basım, H. N. (2015). “Kobi'lerde Çalışanların Kişilik Özelliklerinin Örgütsel Özdeşleşme ve İşten Ayrılma Niyeti Üzerine Etkisinde Psikolojik Sözleşme Algısının Rolü" International Periodical for the Languages, Literature and History of Turkish or Turkic, 10/10, 861-886.

Top, S. (2012). “Çalışanların İşverenleriyle İlgili Duygusal Beklentilerinin Psikolojik Sözleşme Bağlamında Değerlendirilmesi", Süleyman Demirel Üniversitesi Sosyal Bilimler Enstitüsü Dergisi, 1/15, 201-227.

Turnley W. H. and Feldman, D. C. (1999). “A Discrepancy Model Of Psychological Contract Violations", Human Resource Management Rewiew, 9/3, 367-386.

Türker, E. (2010). Psikolojik Sözleşme ile Örgütsel Bağlllık İlişkisi Sağlık Çalışanları Üzerinde Bir Uygulama. (Yüksek Lisans Tezi), Atatürk Üniversitesi Sosyal Bilimler Enstitüsü, İşletme Anabilim Dalı, Erzurum.

Van Knippenberg, D. (2000). "Work Motivation and Performance: A Social Identity Perspective. Applied Psychology" An International Review, 49, 357- 371.

Van Knippenberg, D. and Van Schie, E. (2000). "Foci and Correlates of Organizational Identification", Journal of Occupational and Organizational Psychology, 73, 137-147.

Wei, F. and Si, S. (2013). "Psychological Contract Breach, Negative Reciprocity, and Abusive Supervision: The Mediated Effect of Organizational Identification", Management and Organization Review, 9/3, 541-561.

Zagenczyk T. J. (2011). "Psychological Contracts and Organizational Identification: The Mediating Effect of Perceived Organizational Support", Journal of Labor Research, 32, 254-281.

Zengin, S. (2017). Psikolojik Sözleşme Ve Örgütsel Güven Arasındaki İlişki: Antalya İlinde Faaliyet Gösteren Katılım Bankaları Üzerine Bir Araştırma, Süleyman Demirel Üniversitesi, Sosyal Bilimleri Enstitüsü, İşletme Anabilim Dalı, Isparta. 